\title{
In Situ Chemical Oxidation Through Lance Permeation at the Portsmouth Gaseous Diffusion Plant (PORTS)
}

\author{
M. Z. Martin \\ O. R. West \\ Environmental Sciences Division
}

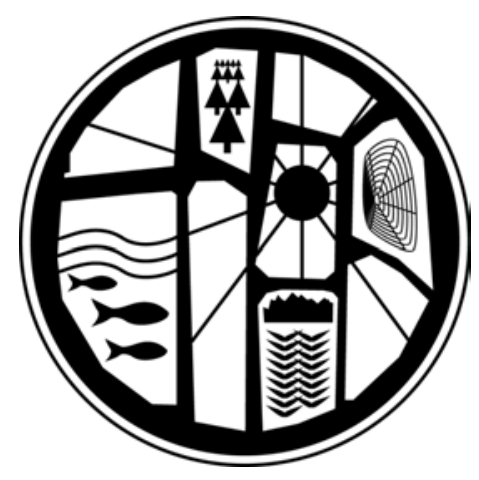




\title{
DOCUMENT AVAILABILITY
}

Reports produced after January 1, 1996, are generally available free via the U.S. Department of Energy (DOE) Information Bridge.

Web site http://www.osti.gov/bridge

Reports produced before January 1, 1996, may be purchased by members of the public from the following source.

\author{
National Technical Information Service \\ 5285 Port Royal Road \\ Springfield, VA 22161 \\ Telephone 703-605-6000 (1-800-553-6847) \\ TDD 703-487-4639 \\ Fax 703-605-6900 \\ E-mail info@ntis.fedworld.gov \\ Web site http://www.ntis.gov/support/ordernowabout.htm
}

Reports are available to DOE employees, DOE contractors, Energy Technology Data

Exchange (ETDE) representatives, and International Nuclear Information System (INIS) representatives from the following source.

Office of Scientific and Technical Information

P.O. Box 62

Oak Ridge, TN 37831

Telephone 865-576-8401

Fax 865-576-5728

E-mail reports@adonis.osti.gov

Web site http://www.osti.gov/contact.html

This report was prepared as an account of work sponsored by an agency of the United States Government. Neither the United States Government nor any agency thereof, nor any of their employees, makes any warranty, express or implied, or assumes any legal liability or responsibility for the accuracy, completeness, or usefulness of any information, apparatus, product, or process disclosed, or represents that its use would not infringe privately owned rights. Reference herein to any specific commercial product, process, or service by trade name, trademark, manufacturer, or otherwise, does not necessarily constitute or imply its endorsement, recommendation, or favoring by the United States Government or any agency thereof. The views and opinions of authors expressed herein do not necessarily state or reflect those of the United States Government or any agency thereof. 


\title{
IN SITU CHEMICAL OXIDATION THROUGH LANCE PERMEATION AT THE PORTSMOUTH GASEOUS DIFFUSION PLANT (PORTS)
}

\author{
M. Z. Martin \\ O. R. West \\ Environmental Sciences Division \\ Oak Ridge National Laboratory
}

Date Published: December 2002

Prepared by

OAK RIDGE NATIONAL LABORATORY

Oak Ridge, Tennessee 37831-6038

managed by

UT-BATTELLE, LLC

for the

U. S. DEPARTMENT OF ENERGY

under contract DE-AC05-00OR22725 



\section{CONTENTS}

\section{Page}

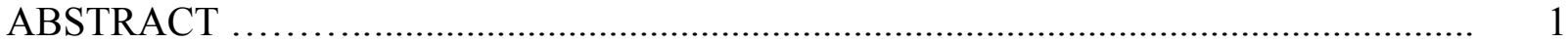

1. TECHNOLOGY DESCRIPTION …………....................................................

2. PERFORMANCE: AUGUST 2000 FIELD TEST AT PORTS …………………....... 2

2.1 BACKGROUND ...................................................................... 2

2.2 SITE HYDROGEOLOGY ................................................................... 5

2.3 FIELD TEST OPERATIONS ................................................................ 5

2.4 PRE- AND POST-TREATMENT MONITORING RESULTS ........................ 5

2.5 ACCIDENT DURING NEUTRALIZATION OF EXCESS $\mathrm{NaMnO}_{4} \ldots \ldots \ldots \ldots . . .7$

3. TECHNOLOGY APPLICABILITY ………………............................................. 8

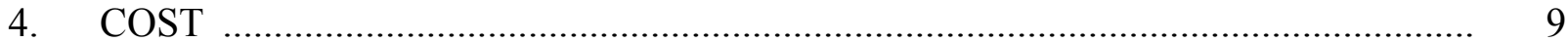

5. REGULATORY, SAFETY, AND HEALTH CONSIDERATIONS ……………….... 10

5.1 REGULATORY AND PLANNING DOCUMENTS..................................... 10

5.2 SAFETY, RISKS, BENEFITS, AND COMMUNITY REACTION WORKER SAFETY …………………………….................................. 10

5.3 COMMUNITY SAFETY .................................................................. 11

5.4 ENVIRONMENTAL IMPACTS....................................................... 11

5.5 SOCIOECONOMIC IMPACTS AND COMMUNITY PERCEPTION .......... 11

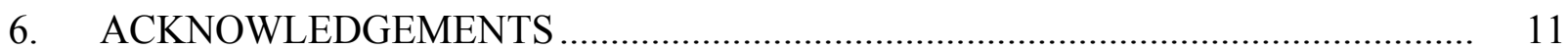

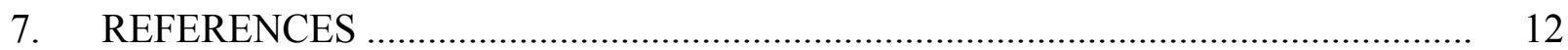

APPENDIX A: COMPARISON OF PRE- AND POST-ISCO-LP TREATMENT

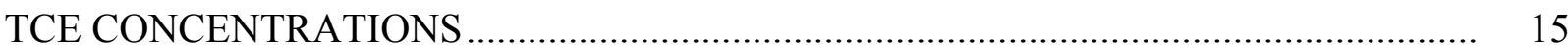

APPENDIX B: COMPARISON OF PRE- AND POST-ISCO-LP TREATMENT MANGANESE SOIL CONCENTRATIONS 



\begin{abstract}
In situ chemical oxidation through lance permeation (ISCO-LP) is an emerging remediation technology in which chemical oxidants (such as potassium or sodium permanganate) are delivered to the subsurface using vertical lance-like injectors. It is applicable to sites with oxidizable contaminants such as chlorinated solvents and fuel hydrocarbons. Because vertical lance injections can be deployed at relatively close spacing, ISCO-LP potentially can be used to clean-up contamination in low-permeability media.

This document provides information that can help potential users determine whether ISCO-LP would apply to a particular environmental management problem. It contains a general description of the technology (Section 2), performance data from a field demonstration (Section 3), an assessment of technology applicability (Section 4), a summary of cost elements (Section 5), and a list of regulatory, environmental safety and health issues (Section 6). It is patterned after the Innovative Technology Summary Reports (ITSR) published by the Department of Energy's (DOE) Office of Science and Technology under the Subsurface Contaminants Focus Area (SCFA). As in the previously published ITSRs, the technology described in this report was developed through funding from SCFA.

Most of the information contained in this report was obtained from a field demonstration of ISCO-LP conducted in July-August 2000 at DOE's Portsmouth Gaseous Diffusion Plant (PORTS). The field test was not completed due to an accident that caused a field worker serious injuries. Although performance assessment data are very limited, the field test highlighted important health and safety issues that must be considered by site managers and technology vendors interested in implementing ISCO-LP.
\end{abstract}

\title{
1. TECHNOLOGY DESCRIPTION
}

In situ chemical oxidation (ISCO) is a rapidly developing class of remediation technologies in which oxidants (e.g., potassium or sodium permanganate, $\mathrm{KMnO}_{4}$ or $\left.\mathrm{NaMnO}_{4}\right)$ and hydrogen peroxide $\left(\mathrm{H}_{2} \mathrm{O}_{2}\right)$ are delivered to the subsurface to degrade organic contaminants such as trichloroethylene (TCE) and tetrachloroethylene (PCE) (Schnarr et al., 1998; Siegrist et al., 2001). The oxidation of TCE by $\mathrm{MnO}_{4}{ }^{-}$ follows a series of sequential reactions, beginning with the rate-limiting formation of a cyclic hypomanganese ester, followed by the rapid decomposition of the ester into carboxylic acids that are then more slowly oxidized by $\mathrm{MnO}_{4}{ }^{-}$to the final product, $\mathrm{CO}_{2}$. From a practical perspective, TCE degradation has been shown to occur relatively rapidly in batch tests where $>99 \%$ reduction in TCE concentration was achieved within 24 hours in soils treated with concentrated $\mathrm{MnO}_{4}{ }^{-}$solutions $($Gates et al., 2000). These tests also show that $\mathrm{MnO}_{4}{ }^{-}$generally resulted in more extensive degradation of TCE and PCE under a wider range of subsurface conditions when compared to $\mathrm{H}_{2} \mathrm{O}_{2}$.

$\mathrm{KMnO}_{4}$ and $\mathrm{NaMnO}_{4}$ are inherently more stable than $\mathrm{H}_{2} \mathrm{O}_{2}$, the latter tending to decompose rapidly to $\mathrm{H}_{2} \mathrm{O}$ and $\mathrm{O}_{2}$ when brought in contact with soil material. $\mathrm{NaMnO}_{4}$ is significantly more soluble than $\mathrm{KMnO}_{4}(\sim 65 \%$ vs $\sim 7 \%$ at room temperature), which allows it to be delivered in more concentrated solutions. This is particularly important in situations where high pore water saturation limits the volume of oxidant that can be injected into the subsurface. Because highly concentrated $\mathrm{NaMnO}_{4}$ solutions can be used, more care is needed in handling such a reactive fluid in the field. There is also no radioactivity associated with $\mathrm{NaMnO}_{4}$, whereas there is a small fraction [0.0117\%] of K-40 in $\mathrm{KMnO}_{4}$. This slight radioactivity posed logistical difficulties at the Portsmouth Gaseous Diffusion Plant, where field methods 
used to screen for radioactivity could not distinguish between K-40 and other radionuclides. Because waste disposal criteria at the plant were based on these field methods, piping used to deliver $\mathrm{KMnO}_{4}$ solutions had to be disposed of as radioactive waste.

As in most in situ remediation technologies involving chemical reagents, effective delivery of the chemical oxidant solution to the subsurface is the key to a successful implementation of ISCO. In previous ISCO field demonstrations, permanganate oxidants were injected into the subsurface using horizontal and vertical wells (West et al. 1997, Lowe et al. 2002). Such an approach would not be effective in fine-grained sediments where oxidant transport is severely limited by low hydraulic conductivities. Lance permeation involves the use of closely spaced vertical lances to penetrate the subsurface to depths of up to $40 \mathrm{ft}$. From each lance tip, oxidant can be injected under pressure into the soil at specified depth intervals providing oxidant delivery and distribution. Spacing of the lances and injection depth intervals can be adjusted depending on site conditions, and can be as small as to 2 to 3 - $\mathrm{ft}$ in low-permeability clays. Using lance permeation, targeted delivery of oxidants to source zones or hot spots is feasible even in tight clays.

When designing a lance permeation treatment scheme, primary consideration is given to injection spacing (horizontal and vertical), pressures, and volumes of oxidant solutions. The latter is determined by the amount required to treat expected contaminant levels through out a target area, as well as provide excess oxidant to be consumed by natural organic matter. It is not always necessary for the entire subsurface to be saturated with oxidant. Concentrated oxidant solutions can be delivered into discrete intervals and allowed to diffuse into the surrounding matrix. Injection spacing can be decreased in areas of higher contaminant concentrations and/or low soil moisture content while increased in areas of lower contaminant concentrations and/or high soil moisture content. The depth of injection limits injection pressures to avoid excessive leakage of the oxidant to the surface.

\section{PERFORMANCE: AUGUST 2000 FIELD TEST AT PORTS}

\subsection{BACKGROUND}

A field demonstration of ISCO-LP was conducted in the summer of 2000 at DOE's PORTS-site, which is located approximately 80 miles south of Columbus, 20 miles north of Portsmouth, and 1 mile east of $U$. S. Route 23, near Piketon in south-central Ohio (Fig. 1). Personnel from Oak Ridge National Laboratory (ORNL) provided technical oversight for the field demonstration as well as pretreatment soil and groundwater characterization. International Technology Corporation (ITC, Knoxville, TN) was the vendor selected for actual execution of ISCO-LP, based a competitive bidding process. ITC designed the specific details of the field test, based on general specifications provided by ORNL. Lance permeation was conducted using a Geoprobe drill rig owned and operated by Miller Drilling Co., Inc. As described in Section 3.5, the field test was aborted due to an accident that seriously injured a field worker. Approximately 1 year after the aborted field test, Environmental Quality Midwest, Inc. (EQM)/CDM Federal designed and executed post-treatment soil and groundwater sampling to evaluate the effects of ISCO-LP on TCE contamination and residual Mn within the zone actually treated. 


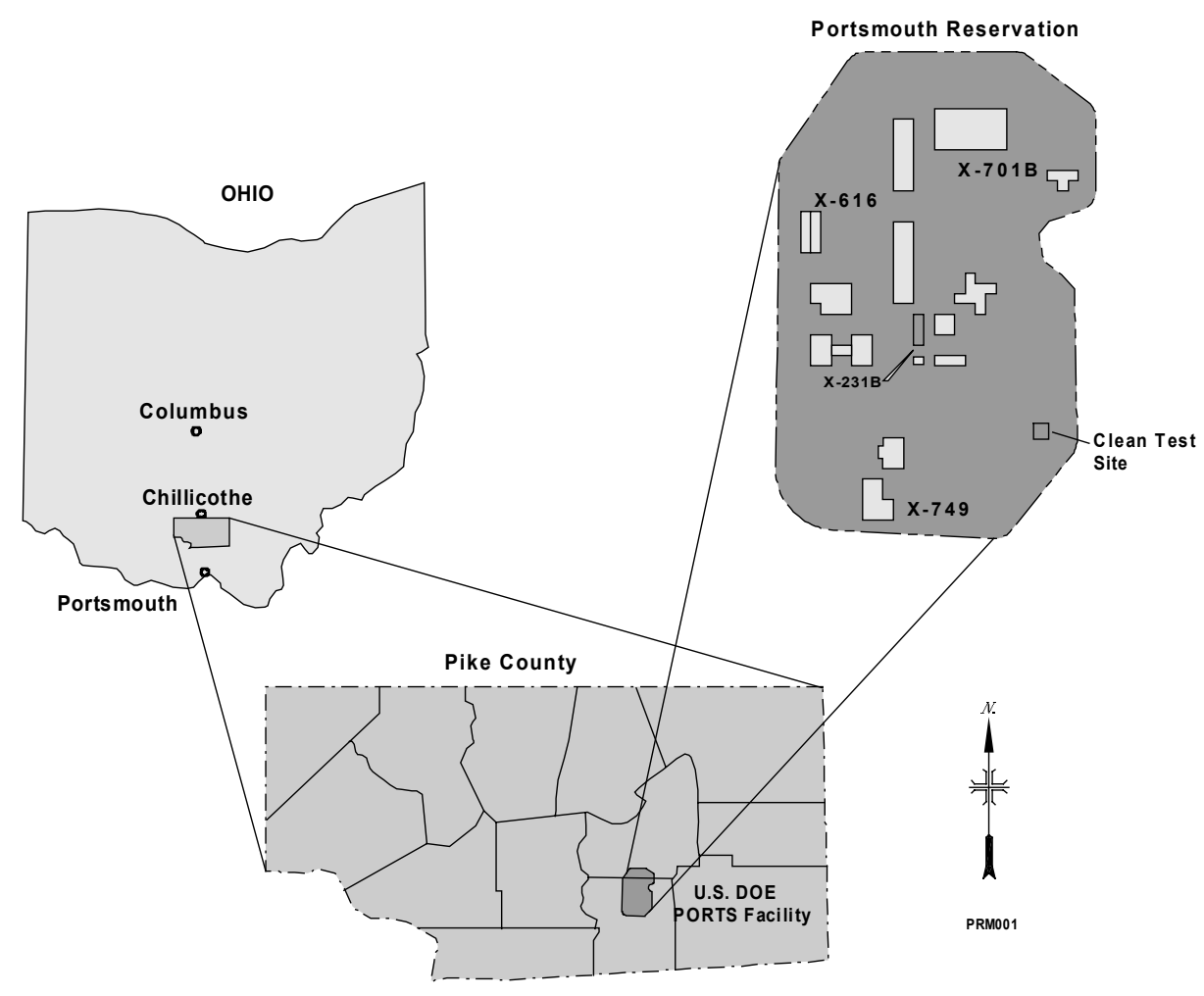

Fig. 1. Location of the Portsmouth Gaseous Diffusion Plant

The X-701B plume area (Fig. 2) within PORTS was chosen as the specific field test site to take advantage of knowledge gained from previous demonstrations at this location (West et al. 1997, Korte et al. 1997). Initial contamination at the site is believed to be from an unlined holding pond that was used for neutralization and settling of metal-bearing acidic wastewater and solvent contaminated solutions. The holding pond was drained and the contaminated sludge and underlying silt and clay were removed as part of a RCRA closure action in 1990. However, recent sampling in the area shows residual TCE contamination in the sediments, as well as a groundwater plume in the underlying silty-gravel aquifer that still persists (Fig. 2), and is migrating offsite in an east-west direction following the general groundwater flow. 

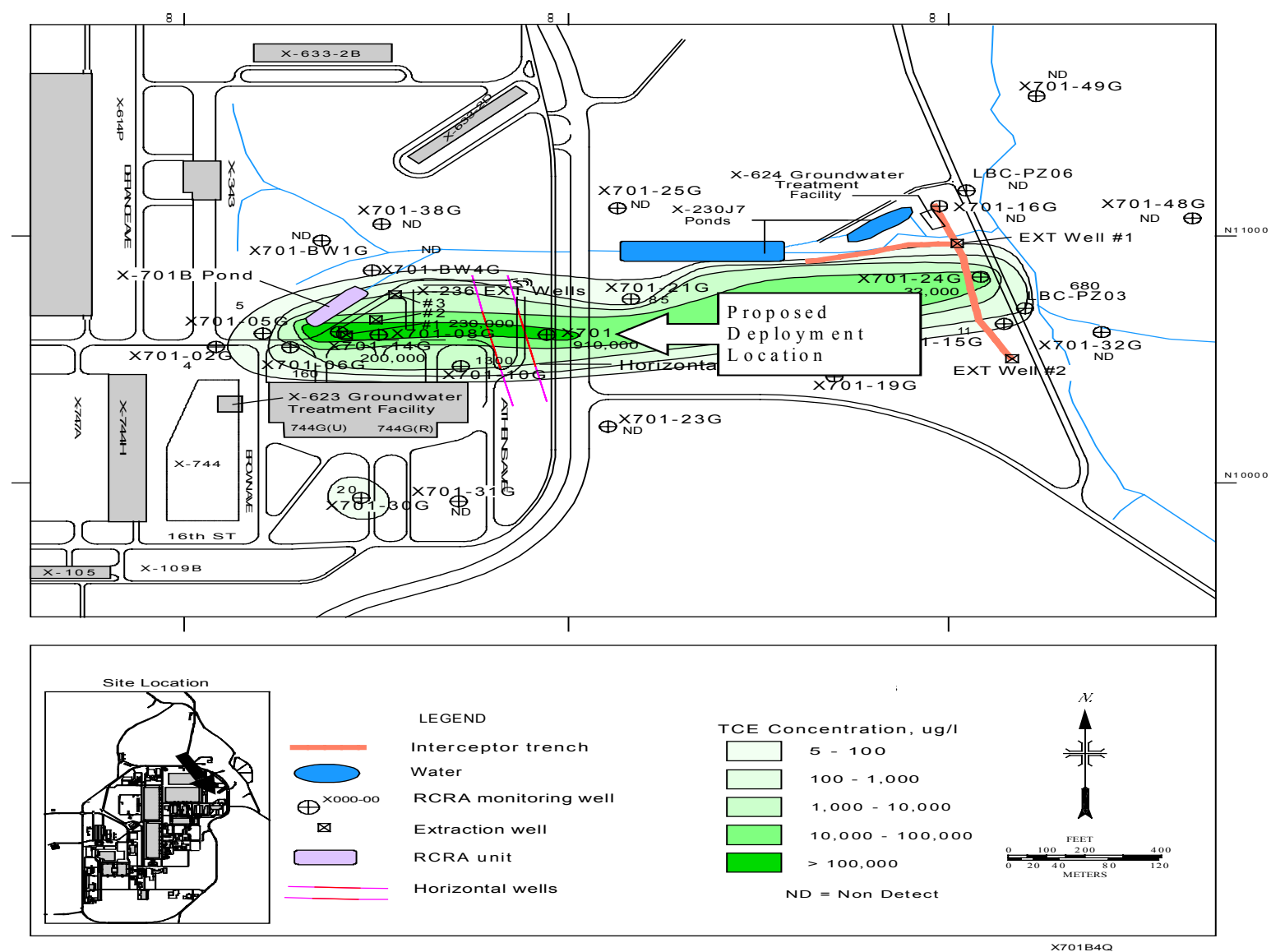

(a)

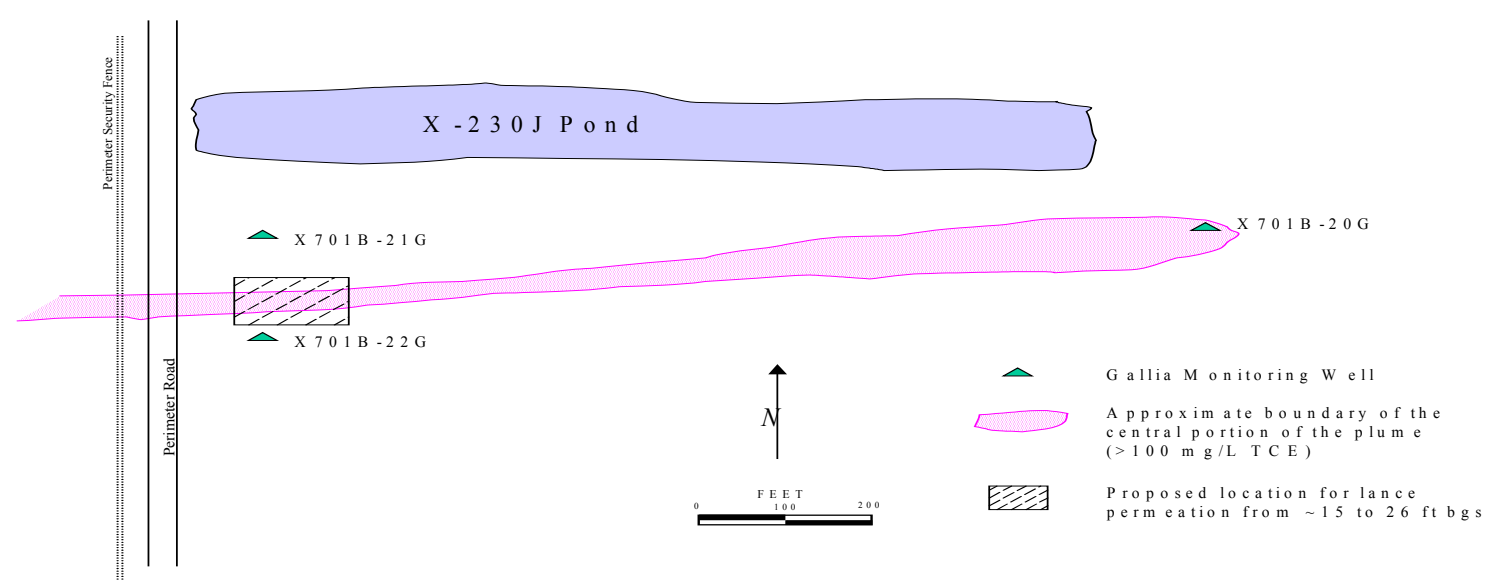

(b)

Fig. 2. The X-701B Plume at PORTS (a) and ISCO-LP field test deployment location (b). 


\subsection{SITE HYDROGEOLOGY}

The stratigraphy underlying the X701-B site consists of the following layers in descending order: (1) the Minford Unit with a thickness of 25 to $30 \mathrm{ft},(2)$ the Gallia Unit with a thickness varying from 2 to $10 \mathrm{ft}$, (3) the Sunbury shale formation (10 to $15-\mathrm{ft}$ thick), and (4) Berea sandstone which is present at an approximate depth of $47 \mathrm{ft}$ in this area. The Minford Unit is divided into an upper clay and a lower silty zone. The Minford upper zone ranges in thickness from 12 to $20 \mathrm{ft}$ and generally consists of stiff, silty clay. The Minford lower silt layer is 8.5 to $18 \mathrm{ft}$ thick.

The Gallia Unit, which lies beneath the Minford, is composed of reddish-brown silty, clayey sand and gravel. The Gallia, which is the primary pathway for groundwater contaminant migration, has a relatively high hydraulic conductivity that varies greatly from $<1 \mathrm{ft} / \mathrm{d}$ to over $400 \mathrm{ft} / \mathrm{d}$. The hydraulic conductivity of the Minford silt member $\left(\sim 10^{-3} \mathrm{ft} / \mathrm{d}\right)$ is significantly lower than that of the underlying Gallia unit, but is higher than that of the overlying Minford clay member $\left(\sim 10^{-4} \mathrm{ft} / \mathrm{d}\right)$. The Gallia unit and the saturated portion of the Minford silt member act as a single water-bearing unit confined above and below respectively by the Minford clay member and the Sunbury Shale formation. Based on groundwater sampling, the latter shale formation has effectively prevented downward migration of contaminated groundwater from the Gallia into the underlying Berea sandstone. The target units for the ISCO-LP field test were the saturated Minford and Gallia. Depth to water within the test site is $\sim 12 \mathrm{ft}$. Depth to the Gallia and Sunbury Shale (i.e., bedrock) are $\sim 25$ and $\sim 32 \mathrm{ft}$, respectively. Pretreatment sampling at the field site showed TCE contamination in the saturated Minford and Gallia sediments ranged from 34 to $369,000 \mathrm{~g} / \mathrm{kg}$ with concentrations consistently increasing with depth. More details regarding pretreatment contaminant concentrations are provided in Section 3.4

\section{FIELD TEST OPERATIONS}

The initial plan for the field test was to deliver a $2 \% \mathrm{NaMnO}_{4}$ solution using lance permeation to the Minford and Gallia over a $180 \mathrm{ft} \times 80 \mathrm{ft}$ area (Fig. 2b). The area was divided into a 10-ft x 10-ft grid and injection points were to be located at the grid nodes. Oxidant was to be injected at 18 to 24-in depth intervals beginning at the water table $(\sim 15 \mathrm{ft} \mathrm{bgs})$ through the saturated Minford and Gallia to the top of the Sunbury to determine the applicability of lance permeation at greater depths and in coarser subsurface soils (i.e, gravels).

Only 44 of the 144 planned injections were completed before the field test was aborted. Because of the accident and aborted work, process details regarding the completed injections (such as oxidant volumes and injection pressures) are not available.

\subsection{PRE- AND POST-TREATMENT MONITORING RESULTS}

Pre-treatment sample collection from 20 boreholes and sample analyses were completed before the field test was aborted. The pretreatment samples were collected by ORNL using the Geoprobe/Terraprobe sampling method at $\sim 2 \mathrm{ft}$ depth intervals from $\sim 15 \mathrm{ft}$ to $32 \mathrm{ft}$ bgs. Each sample was analyzed on-site for TCE and other selected chlorinated hydrocarbons using hexane extraction and a gas chromatograph equipped with an electron capture detector. Onsite sample analysis and sample handling techniques were used to minimize negatively biased TCE analysis results due to volatilization losses. Sediment samples from a number of borings were analyzed for Mn and other metals. 
A year after the aborted field test, EQM/CDM was contracted by Bechtel Jacobs to design and execute post-treatment sampling at the ISCO-LP field test site. Borings for the post-treatment samples were generally collocated with the pre--treatment boreholes, but sampling depth intervals were fixed at 9, 28, and $33 \mathrm{ft}$. Post-treatment sediment samples were collected using a split spoon sample, and samples were analyzed for VOCs and metals at an offsite laboratory. Exact procedures used for handling and preparation of post-treatment samples are not available.

Comparison of the limited post-treatment with pre-treatment performance data shows generally lower TCE concentrations after ISCO-LP (Appendix A). The treatment appeared to be quite effective in degrading TCE within the Gallia, based on a comparison of paired samples at $28 \mathrm{ft}$ (i.e., below the water table) collected before and after treatment (Fig. 3). Unfortunately, the post-treatment samples from the Minford were all collected at $9 \mathrm{ft}$, well above the shallowest oxidant injection depth (at $15 \mathrm{ft}$ bgs). Thus, the effectiveness of ISCO-LP in the low-permeability Minford could not be objectively assessed.

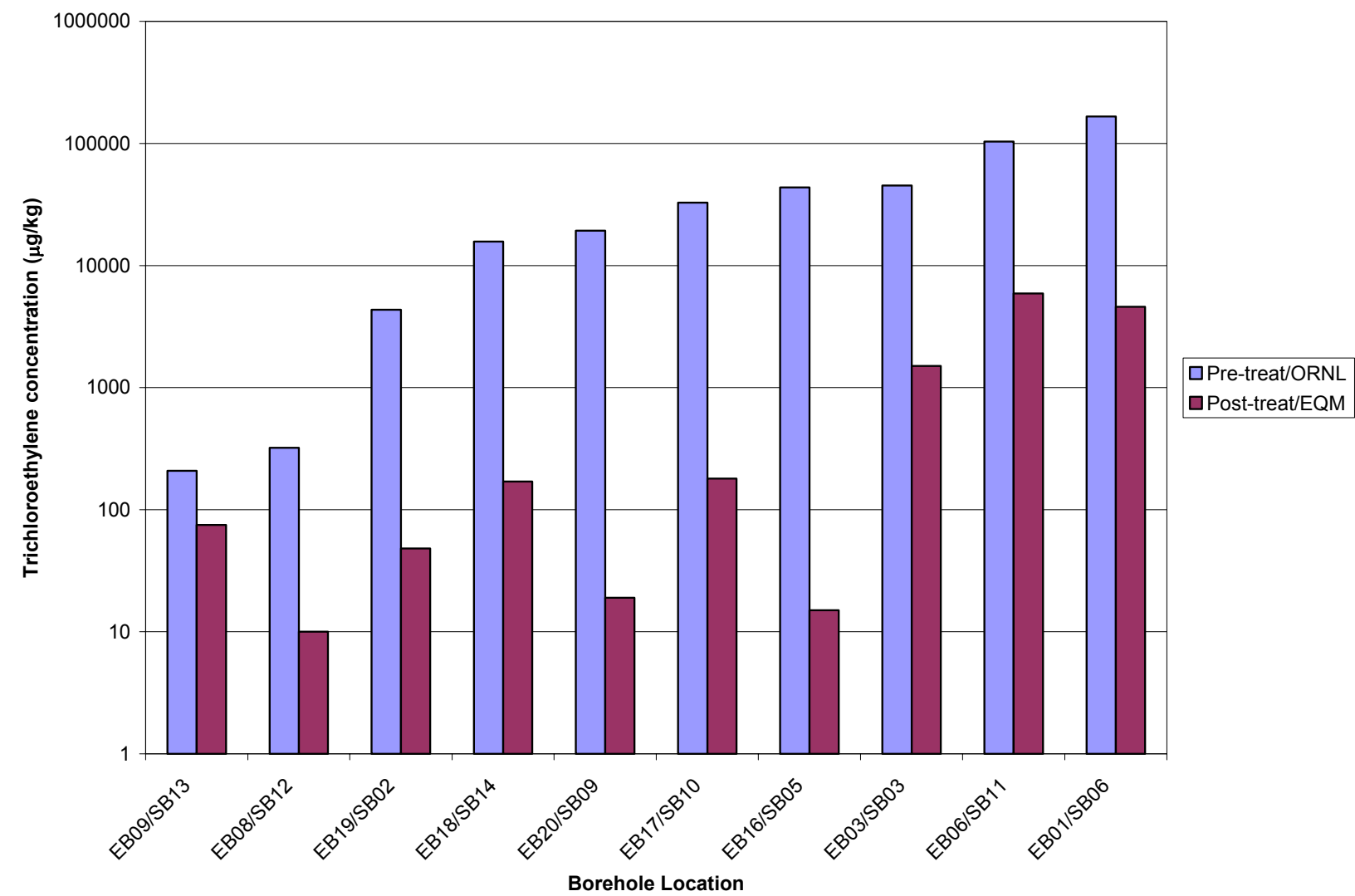

Fig. 3. Comparison of trichlorothylene concentrations in pre- and post-treatment soil samples from $28-\mathrm{ft}$.

Pre-treatment groundwater samples were obtained by ORNL from temporary 1-in PVC monitoring wells, which were installed in some of the boreholes. Post-treatment samples could not be collected from these temporary wells because well construction data were not available to EQM/CDM. Instead, post-treatment groundwater samples were collected from four permanent Gallia monitoring wells in the vicinity of the 
ISCO-LP field test. TCE in Well X701-21G north of the ISCO-LP field test site (see Fig. $2 \mathrm{~b}$ for location) was measured at $87 \mathrm{ppb}$, a significant drop from historical TCE concentrations that ranged from 1000 to $10000 \mathrm{ppb}$. This decrease may be a direct result of the ISCO-LP treatment and/or previous ISCO field demonstrations conducted upstream of this well (West et al. 1998). TCE concentrations in the other three wells sampled after the field test were not significantly different from pretreatment levels.

There were no discernable differences in Mn soil concentrations before and after ISCO-LP. Dissolved $\mathrm{Mn}$ in post-treatment groundwater samples ranged from 0.01 to $6.28 \mathrm{mg} / \mathrm{L}$; historical values for the entire $\mathrm{X}-701 \mathrm{~B}$ site range from 0.02 to $112 \mathrm{mg} / \mathrm{L}$ (EQM/CDM 2001). It appears that the ISCO-LP field test did not lead to significant increases in Mn levels, this may very well be due to the small volume of oxidant that was injected during the field test.

\subsection{ACCIDENT DURING NEUTRALIZATION OF EXCESS $\mathrm{NaMnO}_{4} \mathrm{SOLUTION}^{-}$}

During the ISCO-LP field test, a field worker was seriously injured from a violent chemical reaction. The field worker was neutralizing approximately 3 gal of sodium permanganate solution of unknown concentration contained in a 5-gal bucket. The solution came mostly from liquids drained or pumped out of the Geoprobe drill rods. Oxidant solution was being delivered to the Geoprobe tip through a pressurized line that was threaded through the drill rods. The reason behind the unexpected buildup of oxidant-laden fluids in the drill rods was not investigated but may be either from leakage of the pressurized line, or from overly rapid or pressurized injection into a saturated low-permeability deposit (i.e., the Minford).

To neutralize the oxidant-laden (purple) liquid, the field worker dropped an unknown amount of crystalline sodium thiosulfate (a strong reducing agent) into the 5-gal bucket. A violent explosion from a steam bubble ensued, which resulted in solution being sprayed at least $15-\mathrm{ft}$ into the air. The field worker was sprayed by the airborne solution and suffered from third degree burns. A drilling assistant, who was standing within a few feet of the explosion, was also sprayed by the airborne solution but was not seriously injured.

For disposal of concentrated (40\%) $\mathrm{NaMnO}_{4}$ solutions, the material safety data sheet (MSDS) for Liquiox (a commercially available concentrated $\mathrm{NaMnO}_{4}$ solution used for the ISCO-LP field test) recommends dilution to $\sim 6 \%$ and reduction with sodium thiosulfate. The health and safety plan for the ISCO-LP field test specified that dilute $\mathrm{NaMnO}_{4}$ solutions ( 0 to $6 \mathrm{~g} / \mathrm{L}$ ), including excess injection fluids, will be neutralized with the gradual addition of crystalline sodium thiosulfate. The injection fluid used during the ISCO-LP field test was $\sim 2 \%$, significantly more dilute than what the Liquiox MSDS recommended for neutralization. It is possible that the oxidant-laden liquid drained from the drill rod was not exactly of the same composition and may have been more concentrated than the injection solutions, although it is difficult to see how the latter can occur. The explosion was more likely caused by the rate at which the field worker added the crystalline thiosulfate to the 5-gal bucket of oxidant-laden fluid. Nevertheless, it is apparent that the hazards of the neutralization process were not clearly identified and adequately conveyed to the field workers. A detailed analysis of the accident was conducted by DOE and is documented in an accident investigation report (October 2000, Oak Ridge Operations, US DOE). 


\section{TECHNOLOGY APPLICABILITY}

The following is a list of factors that need to be considered when evaluating the applicability of ISCO-LP for a particular contaminated site.

1. Oxidizability of the target contaminant(s). The chemical oxidant must be capable of degrading the target contaminants under the site-specific geochemical environment. This is best evaluated through laboratory treatability studies using soil/sediment samples from the site.

2. Depth of contamination. Depth limitations are related to the specific drilling equipment that will be used as lances (e.g., the Geoprobe drill rig in the PORTS ISCO-LP field test). Contamination shallower than $100 \mathrm{ft}$ can potentially be treated, but shallower depth constraints may be necessary for certain drill rigs and geotechnical conditions. The depth is also limited by the time required to complete an individual lance penetration, which must be short enough such that areas can be cleaned up within a reasonable amount of time.

3. Areal extent of contamination. ISCO-LP is best applied to hot spots and source zones rather than to large (i.e., mile-long) groundwater plumes.

4. Geotechnical and hydraulic characteristics of contaminated unit. Drilling and oxidant injection rates, and time required for treatment, are affected by the geotechnical and hydrogeological nature of the sediments. ISCO-LP is potentially applicable to low-permeability media but finegrained and consolidated saturated media may pose problems. The hydrogeologic properties of the Minford at PORTS are probably near the limits of ISCO-LP applicability.

5. Underground man-made structures (i.e., buried pipelines and other utilities, underground storage tanks). These can present short-circuits for the injected fluids. The potential for ISCO-LP to negatively impact such structures both mechanically and chemically should also be evaluated.

6. Vertical accessibility of contamination. Equipment needed for lance permeation must be able to access the contaminated zone from the surface. Drill rigs capable of angled penetrations can be used for contamination under surface structures.

7. Presence of nearby groundwater seeps into surface waters. Permanganate solutions impart a purple color even at very low concentrations. In the long-term, excess permanganate not consumed by contaminants will react with natural organic matter as the oxidant moves through the subsurface. In situations where surface waters are very near the contaminated site, ISCO-LP may cause surface seepage of purple liquid that is aesthetically undesirable.

8. Oxidant demand of contaminated sediments. ISCO probably is not optimal for soils with very high natural organic content because larger amounts of oxidant will be needed, resulting in high treatment costs.

9. Co-contaminant metals. Mobility of some metals (e.g. $\mathrm{U}, \mathrm{Cr}$ ) is strongly influenced by its oxidation state, with mobility increasing at higher oxidation states (e.g U(VI) versus U(IV); $\mathrm{Cr}(\mathrm{VI})$ versus $\mathrm{Cr}(\mathrm{III})$ ). Inadvertent mobilization of co-contaminant metals by ISCO should be considered. 


\section{COST}

The major elements of cost for an ISCO-LP implementation are: (1) reagents (KMnO4 or NaMnO4), (2) mobilization, (3) lancing equipment rental/operation, (4) labor costs for field workers (i.e., equipment operators, personnel in charge of mixing oxidant solutions, sampling and performance monitoring, safety officers) and (5) waste disposal. Waste generation generally be limited to excess $\mathrm{KMnO}_{4}$ or $\mathrm{NaMnO}_{4}$ solutions, which can be neutralized in the field. (see Section 6 for safety considerations).

The following is a general approach to estimating the cost for ISCO-LP at a given site:

1. Based on site characterization data and laboratory treatability studies, determine the mass of oxidant per unit volume of soil required to degrade the expected mass of contaminants as well as to satisfy the natural oxidant demand.

2. Select the concentration of oxidant solution to be used, based on handling issues (e.g., dilute solutions are more desirable). Using the selected oxidant concentration and required mass of oxidant from (1), calculate the volume of oxidant solution needed per unit volume of soil.

3. Estimate the dispersion radius or radius of influence for an individual lance penetration. This is best achieved through field tests, but as this technology becomes more widespread, general rulesof-thumb will emerge.

4. The dispersion radius is used to determine number of lance penetrations needed to treat a given area.

5. Select the number of injection depth intervals for an individual lance penetration. This is also best achieved through field tests.

6. Calculate the time required to complete an individual lance penetration using the number of injection depth intervals (step 5), the dispersion radius (step 3), amount of oxidant solution needed per volume of soil (step 2), the oxidant injection and the drilling rate (based on operator experience).

7. Calculate the total time required to treat a given area using the estimated number of lance penetrations (step 4)and the time required to complete an individual permeation (step 6).

8. Estimate the number of personnel needed in the field. Calculate the total labor and equipment operation costs for cleaning the entire site based on the total time estimated for treatment (step 7) and unit labor and equipment operating costs.

9. Total treatment cost $=$ labor cost + equipment rental/operating cost + reagent cost + waste disposal + mobilization/travel + plan preparation + permitting + incidental supplies (e.g., mixing equipment, vials for soil samples).

The ITC subcontract for conducting oxidant injections for the ISCO-LP field test at PORTS was priced at $\$ 338 \mathrm{~K}$. This subcontract covered process design, preparation of plan, permitting and approval, mobilization, oxidant injections, and report writing. It excluded soil sampling and analysis for 
performance monitoring. Thus, based on a $244,800 \mathrm{cu}$. ft. treatment volume, the unit cost for the ISCOLP would have been $\sim \$ 37 /$ cu.yd. This is a hypothetical cost because the field test was not completed as planned.

\section{REGULATORY, SAFETY, AND HEALTH CONSIDERATIONS}

\subsection{REGULATORY AND PLANNING DOCUMENTS}

A number of regulatory considerations were addressed before deployment of the ISCO-LP field test. The permits and paperwork that was prepared is listed below:

- Health and Safety Plan,

- Underground Injection Permit

- Comprehensive Environmental Recovery, Compensation, and Liability Act (CERCLA)

- Resource Conservation and Recovery Act (RCRA)

- National Environmental Protection Act review was required

In case of field tests, additional requirements are,

- Environmental Technology Section Procedures which included a Technical Work Plan,

- Generator's Waste Management Plan,

- Quality Assurance Project Plan,

- Prior to deployment of the lance permeation portion of the contract, a Site Operational Review Committee document was submitted. This evaluated project readiness to start work which includes:

1. summary description of scope of the work,

2. review needs evaluation form,

3. project schedule,

4. project location,

5. list of plans and relevant work,

6. process controls,

7. training requirements,

8. activity hazard analysis

\subsection{SAFETY, RISKS, BENEFITS, AND COMMUNITY REACTION WORKER SAFETY}

- Worker safety risks are those associated with work at a contaminated site especially handling of hazardous chemicals and association with standard construction operations.

- Major potential risk to workers can occur during the handling of the reactive oxidant (e.g., concentrated permanganate solution). The $\mathrm{NaMnO}_{4}$ solution is a strong oxidizer and has to be kept away from combustibles. Spills have to be avoided and this material must be isolated from sparking equipment.

- A vital lesson learned from the ISCO-LP field test is that a clear understanding of the hazards of the neutralizing process (using thiosfulate for reducing excess permanganate solutions) must 
be conveyed to field workers. Precise instructions on how to handle and neutralize oxidant solutions must be provided.

- A prerequisite for all field personnel is a 40-h Occupational Safety and Health Administration training. This is a requirement in the 29 Code of Federal Regulations (CFR) 1910.120 for hazardous waste operations.

\subsection{COMMUNITY SAFETY}

- The chemicals used for ISCO-LP pose no hazard to the community as a whole due to their low concentrations after dispersal into the soil and groundwater.

- The by-products generated are also not considered to be harmful to the community. These are $\mathrm{CO}_{2}, \mathrm{MnO}_{2}$ solids, cations (e.g., sodium and potassium), and halides.

- In situ chemical oxidation using $\mathrm{KMnO}_{4}$ and $\mathrm{NaMNO}_{4}$ does not cause release of volatile organic compounds.

- Transportation safety concerns are covered by the subcontracting agencies. There have been no unusual or significant concerns in connections with materials and equipment used in this technology.

\subsection{ENVIRONMENTAL IMPACTS}

Summarizing the points addressed in "Community Safety" the environmental impacts are as follows:

- Potassium permanganate and sodium permanganate are considered to be safe in the environment since the concentration is very low when it is dispersed into the soil and groundwater.

- Negligible by-products have been mentioned in the preceding paragraph.

- No volatile organic compounds are produced due to oxidation of the contaminants.

\subsection{SOCIOECONOMIC IMPACTS AND COMMUNITY PERCEPTION}

It is well known that the economic and labor force impacts are minimal in case of implementing in situ remediation technologies used for DNAPLs.

The familiarity of the general public with in situ technologies such as chemical oxidation using potassium and sodium permanganate is low, but explaining and education of the public can be accomplished with ease since these technologies are similar to wastewater treatment methods.

\section{ACKNOWLEDGEMENTS}

We would like to express our appreciation to the following people whose help greatly benefited this study: Cindy Kendrick and Elizabeth Phillips for their programmatic information and valuable suggestions; John Sokol, from Bechtel Jacobs, for the last follow-up sampling report that provided much information about the technology. We would also like to thank Kathryn Lowe from the Colorado School of Mines for providing the initial reports on lance permeation 
and in situ chemical oxidation through recirculation field experiments. Our thanks go to Karen Bradley from ORNL Procurement who provided much assistance in returning the chemicals and other equipment that remained at the PORTS site. We would also like to thank Tom Early and William Doll (ORNL) for reviewing this report and their valuable suggestions.

\section{REFERENCES}

Schnarr, M.; Truax, C.; Farquhar, G.; Hood, E.; Gonully, T.; Stickney, B. 1998. "Laboratory and controlled field experimentation using potassium permanganate to remediate trichloroethylene and perchloroethylene DNAPLs in porous media," Journal of Contaminant Hydrology, 29, 205.

Siegrist, R. L.; Urynowicz, M. A.; West, O. R.; Crimi, M. L.; Lowe, K. S. 2001. Principles and Practices of In Situ Chemical Oxidation using Permanganate. Battelle Press, Columbus, OH.

Gates-Andersen, D.D.; Siegrist, R.L.; Cline, S.R. 2001. "The effect of oxidant type and environmental conditions on the chemical oxidation of organic contaminants in soil," Journal of Environmental Engineering, 127(4):337-347.

West, O. R.; Cline, S. R.; Holden, W. L.; Gardner, F. G.; Schlosser, B. M.; Thate, J. E.; Pickering, D. A.; Houk, T. C. 1998. A Full-scale Demonstration of In Situ Chemical Oxidation through Recirculation at the X-701B Site, Oak Ridge National Laboratory, Oak Ridge, TN, ORNL/TM-13556.

Korte, N.; Muck, M.; Kearl, P.; Siegrist, R.; Houk, T. ; Schlosser, R.; Zutman, J. 1997. Field Evaluation of a Horizontal Well Recirculation System for Groundwater Treatment: Field Demonstration at X-701B Portsmouth Gaseous Diffusion Plant, Piketon, Ohio. Oak Ridge National Laboratory, Grand Junction, CO.

Oak Ridge National Laboratory. July 1999. Lance Permeation of the Low Permeable Minford Member and In Situ Chemical Oxidation through Recirculation of the Gallia Member at X-701B: Technical Work Plan. Submitted to the Portsmouth Gaseous Diffusion Plant, Piketon, OH.

Oak Ridge National Laboratory. July 1999. Lance Permeation of the Low Permeable Minford Member and In Situ Chemical Oxidation through Recirculation of the Gallia Member at X-701B: Health and Safety Plan. Submitted to the Portsmouth Gaseous Diffusion Plant, Piketon, OH.

Purchase order and Statement of Work from UT-Battelle Subcontract number 4000001075, February 14, 2000. Vendor: International Technology Corp, 312 Directors Drive, Knoxville, TN 37923-4799.

EQ Midwest, Inc./CDM Federal Programs Corporation. October 2001. Evaluation of the X-701B In situ Chemical Oxidation Injection Site at the Portsmouth Gaseous Diffusion Plant, Piketon, OH. DOE/OR/11-3090\&D1.

Oak Ridge Operations (U. S. DOE), October 2000. Type B Accident Investigation, Injury Resulting form Sodium Thiosulfate and Sodium Permanganate Violent Exothermic Reaction at X-701B Site, Portsmouth Gaseous Diffusion Plant, $\mathrm{OH}$. 
APPENDIX 



\section{APPENDIX A:}

\section{COMPARISON OF PRE- AND POST-ISCO-LP TREATMENT TCE CONCENTRATIONS (EQM/CDM 2001)}

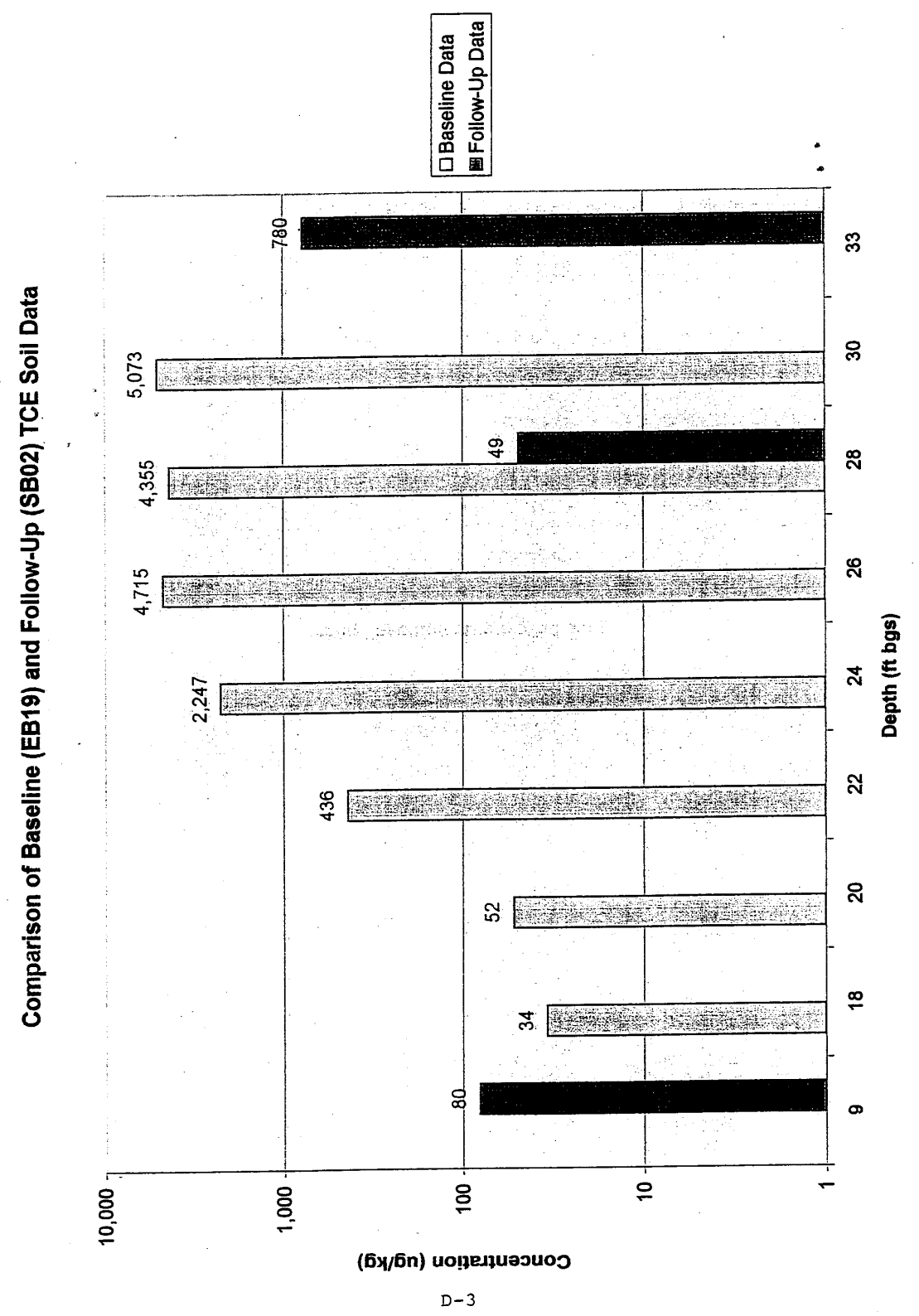




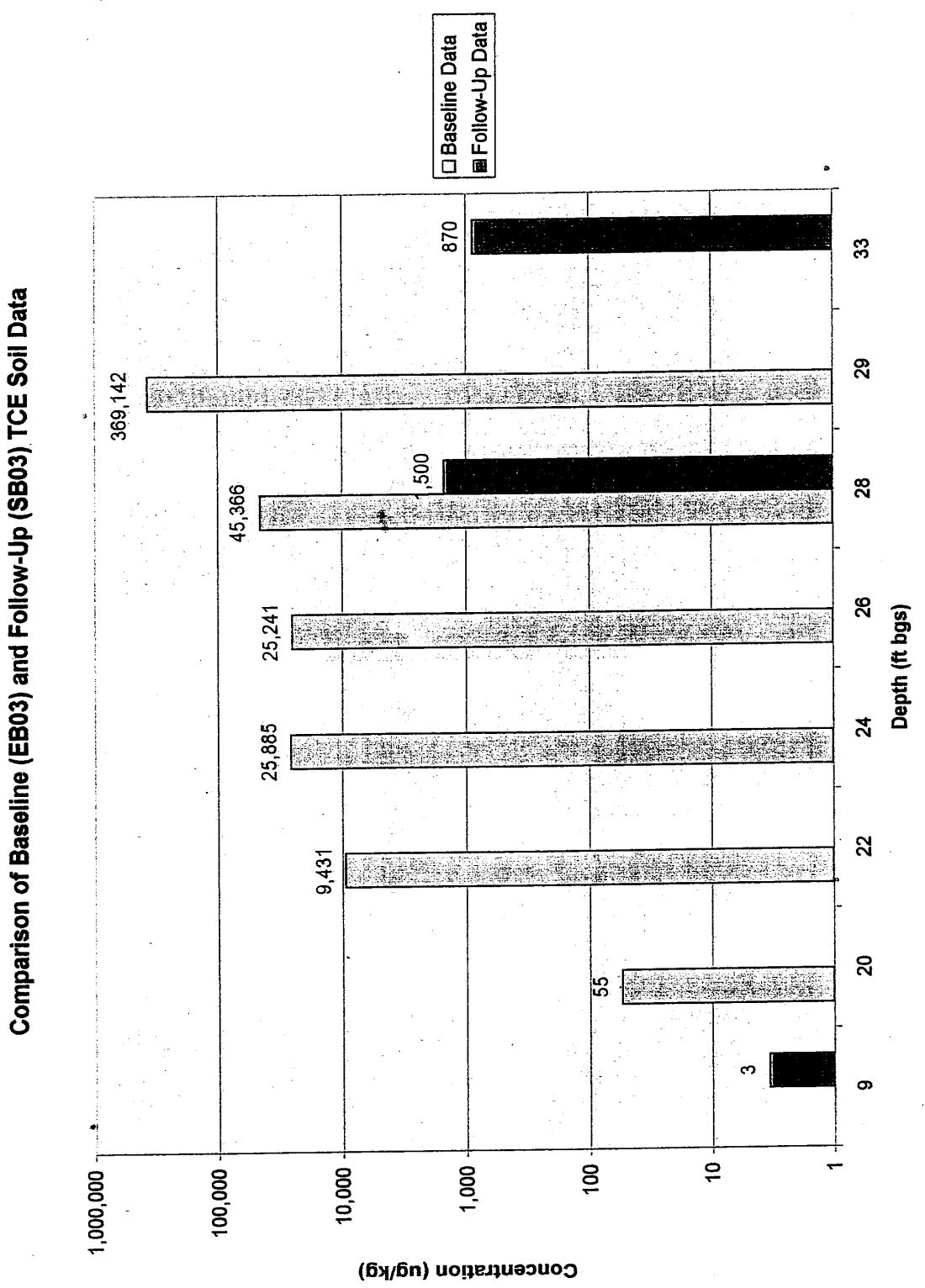




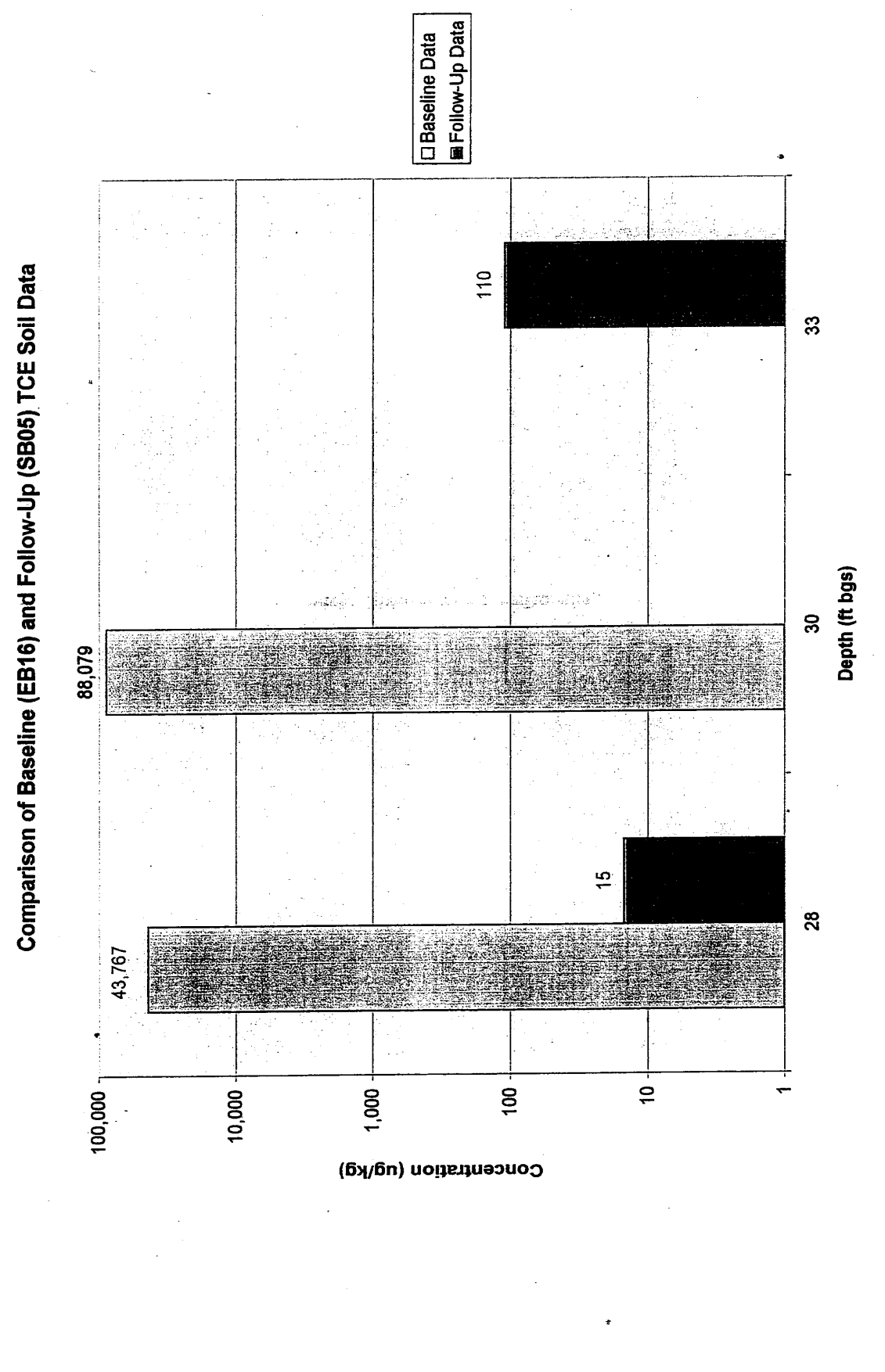




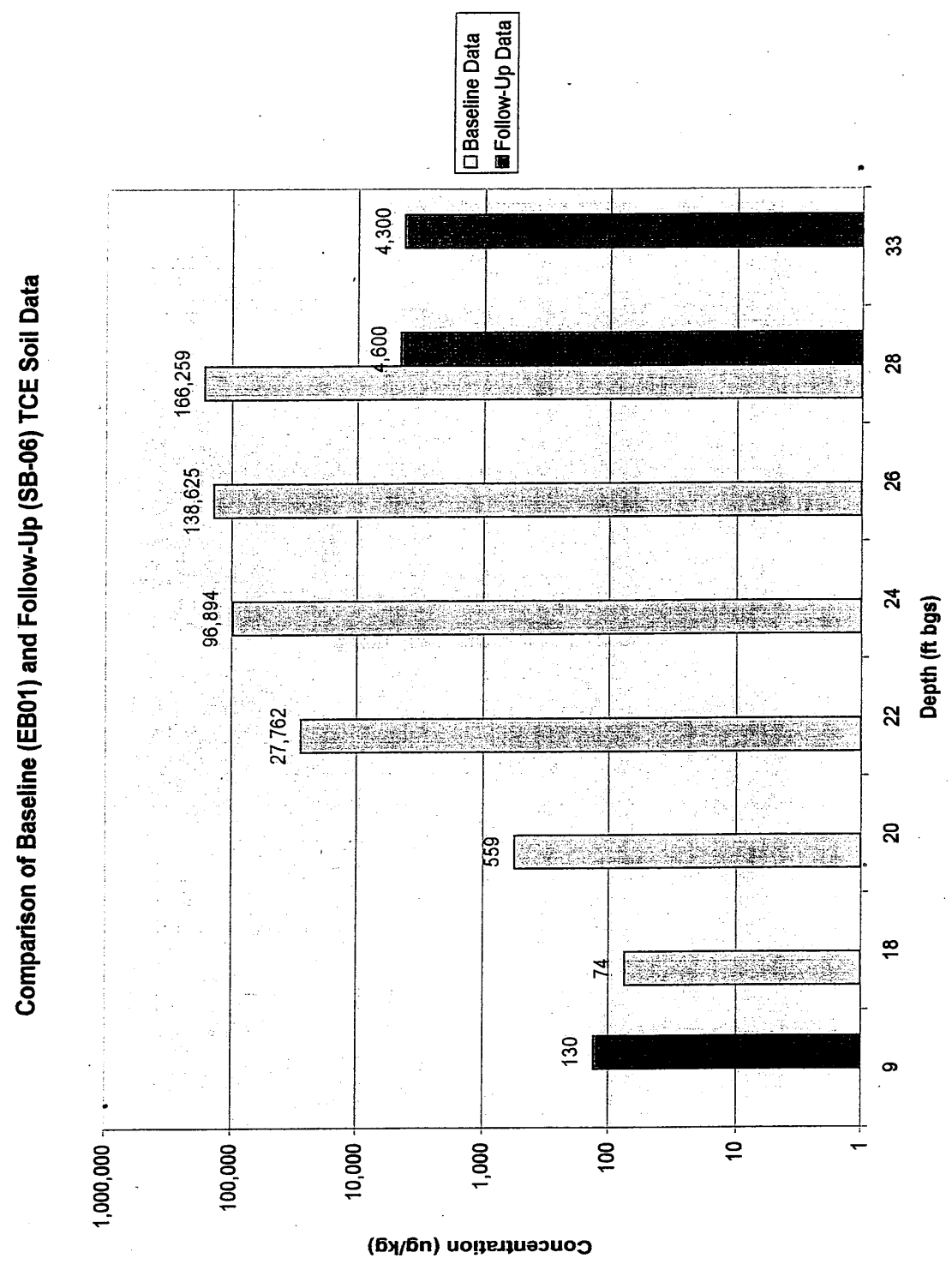




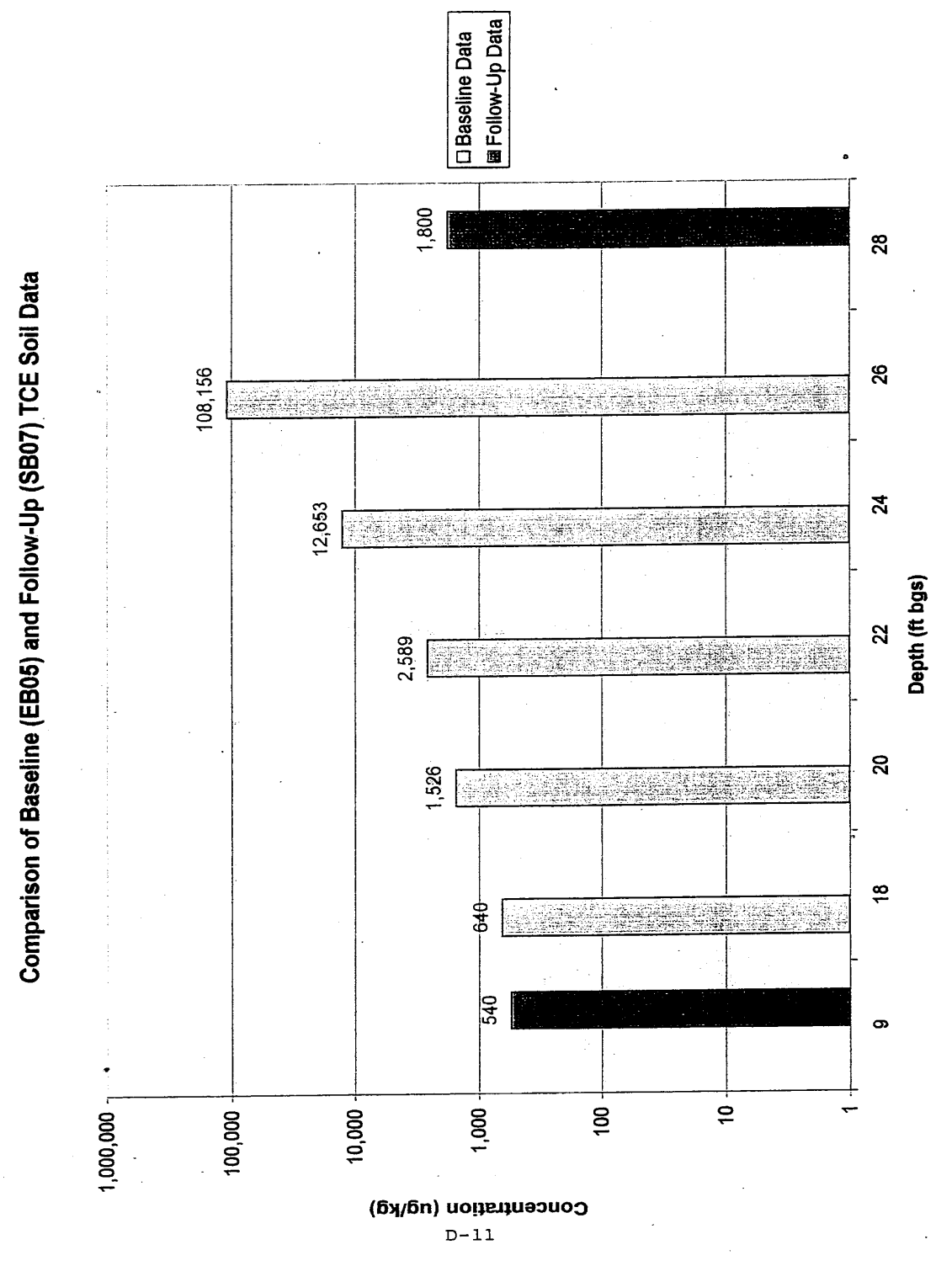




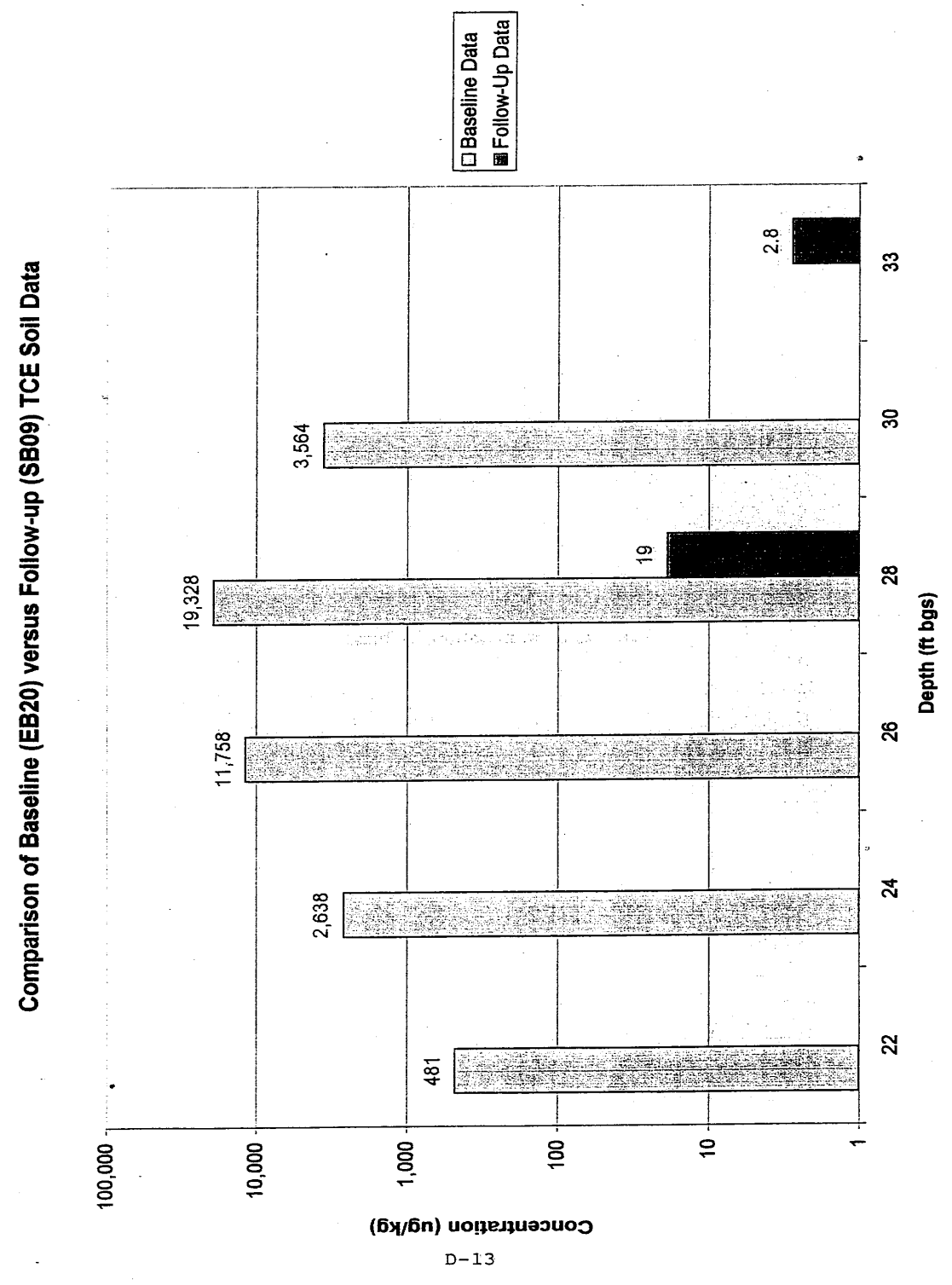




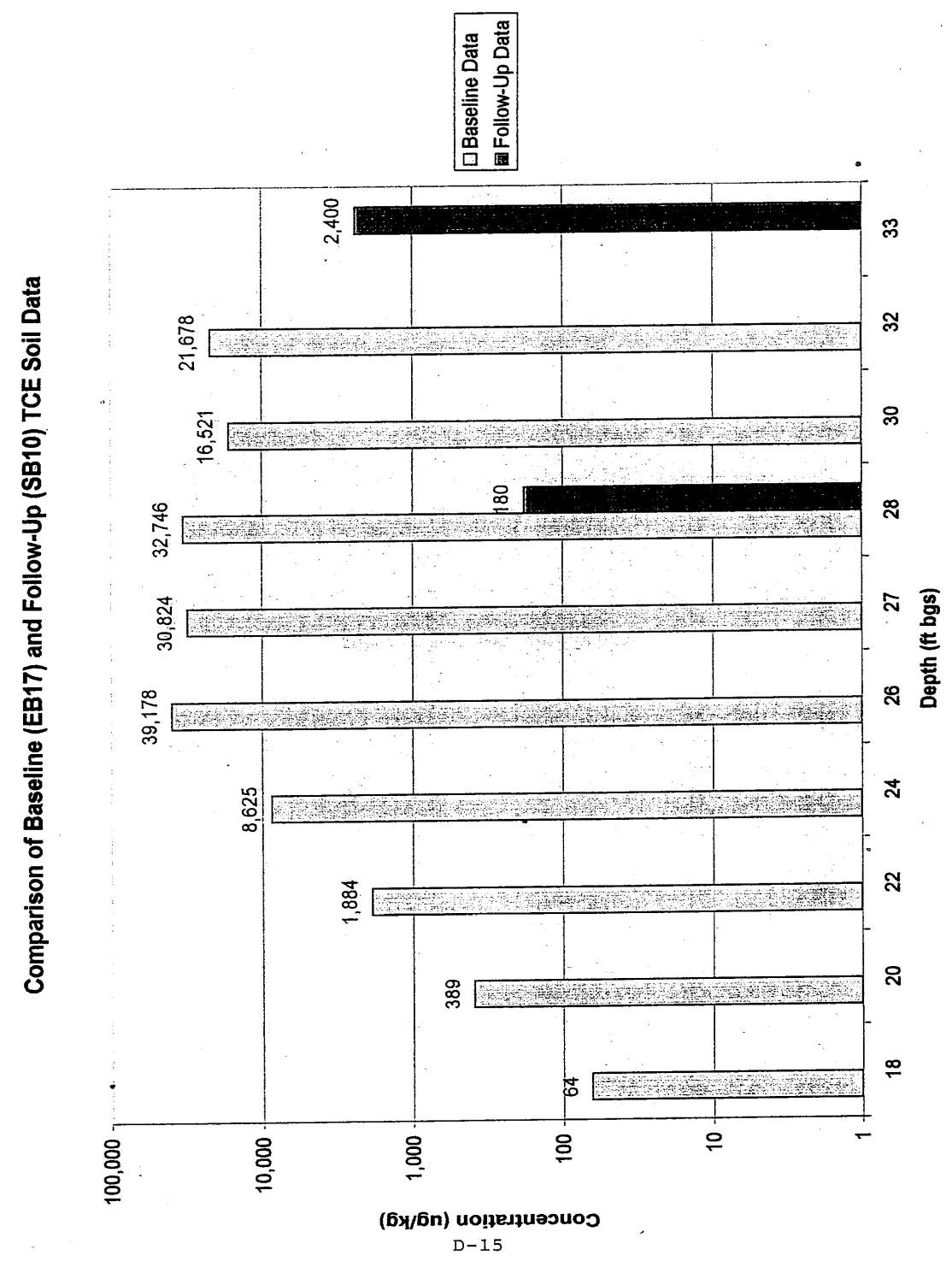




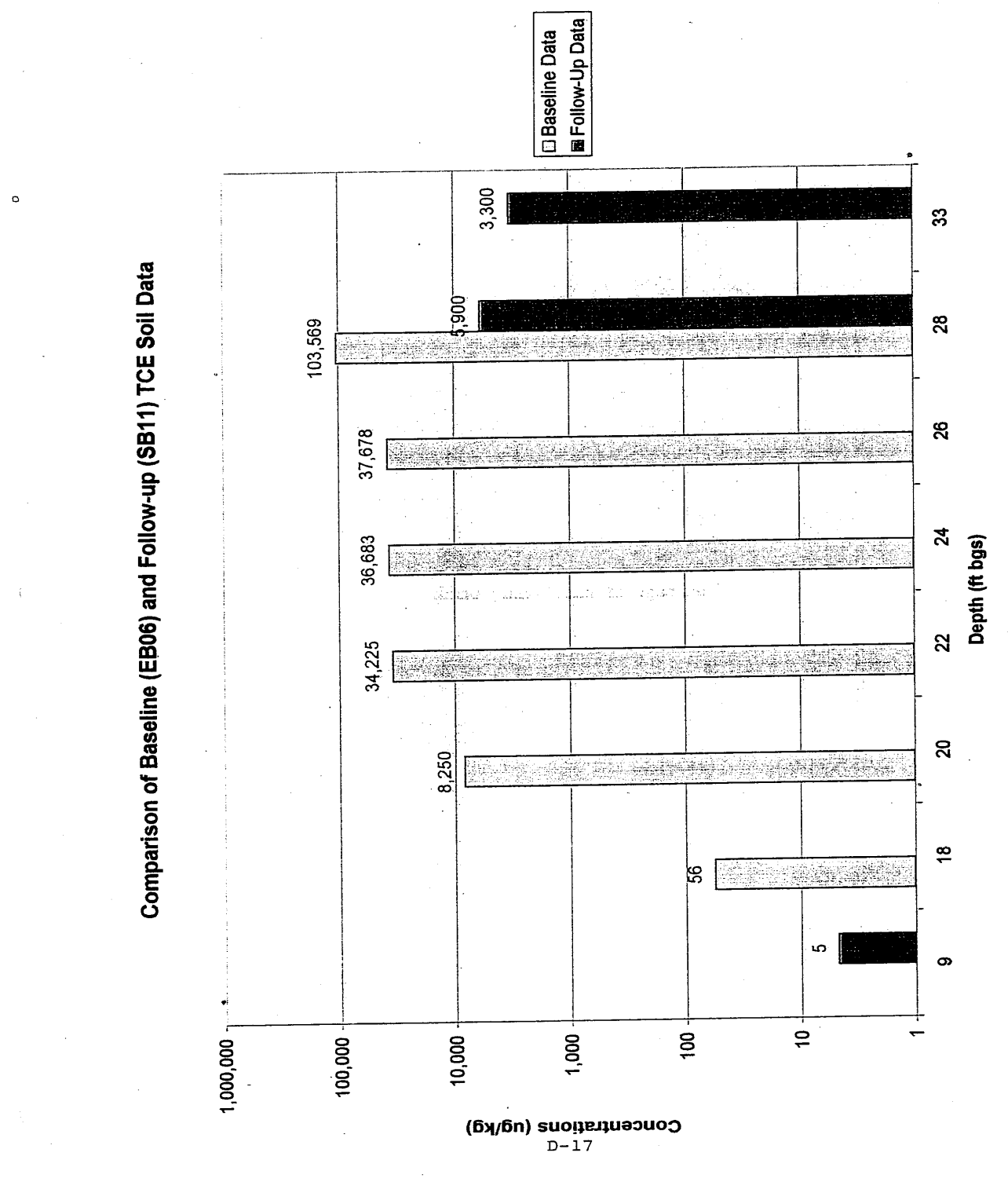




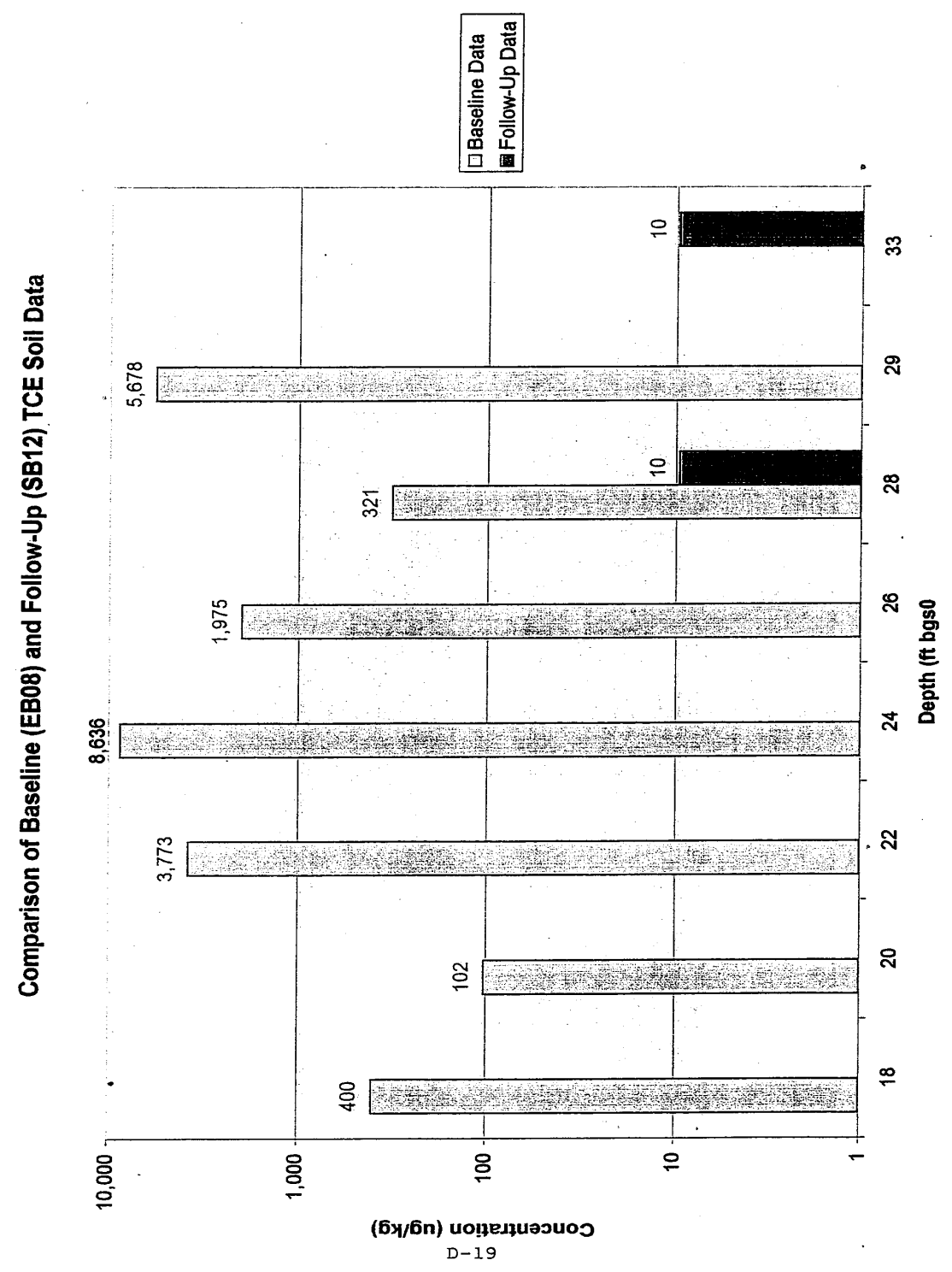




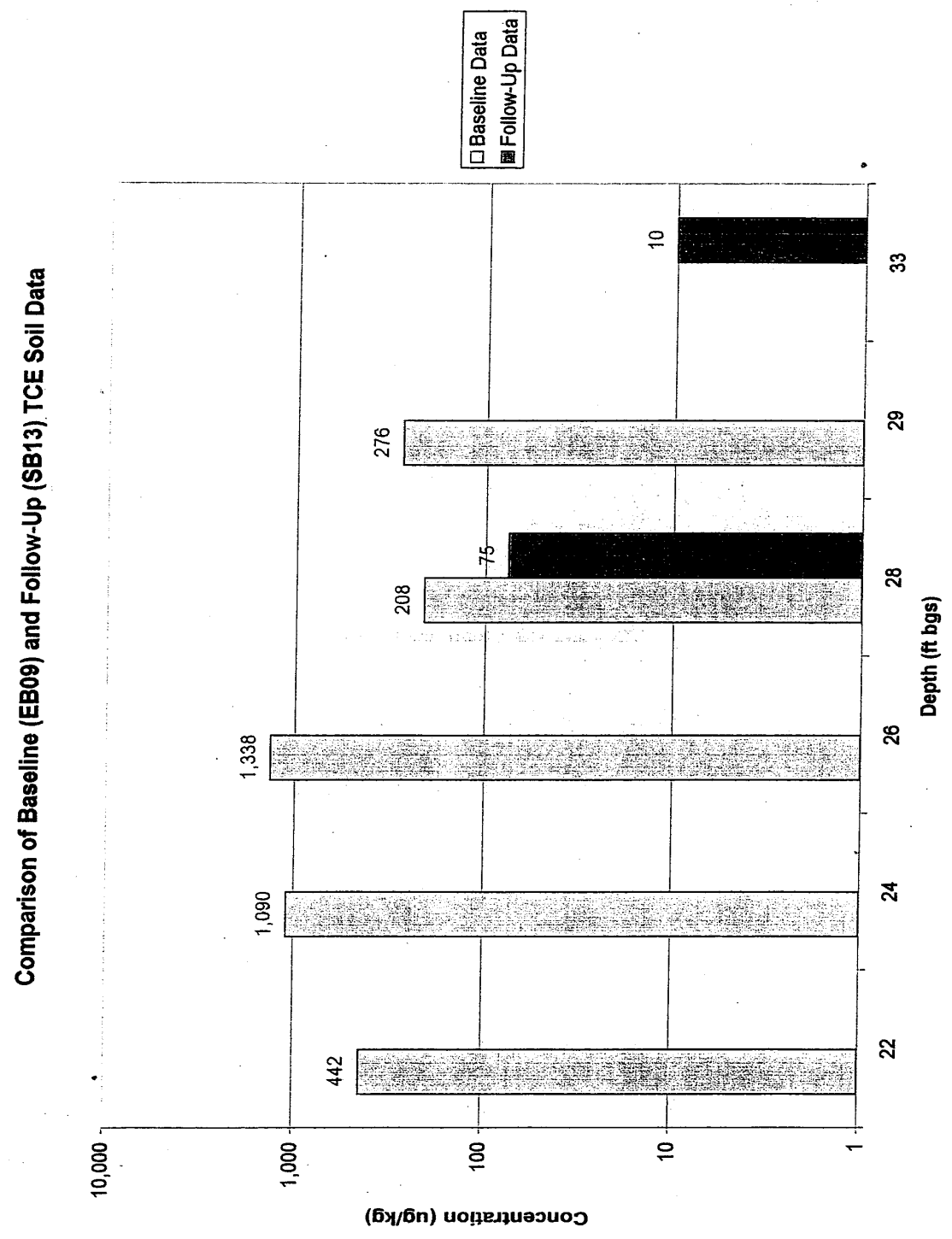




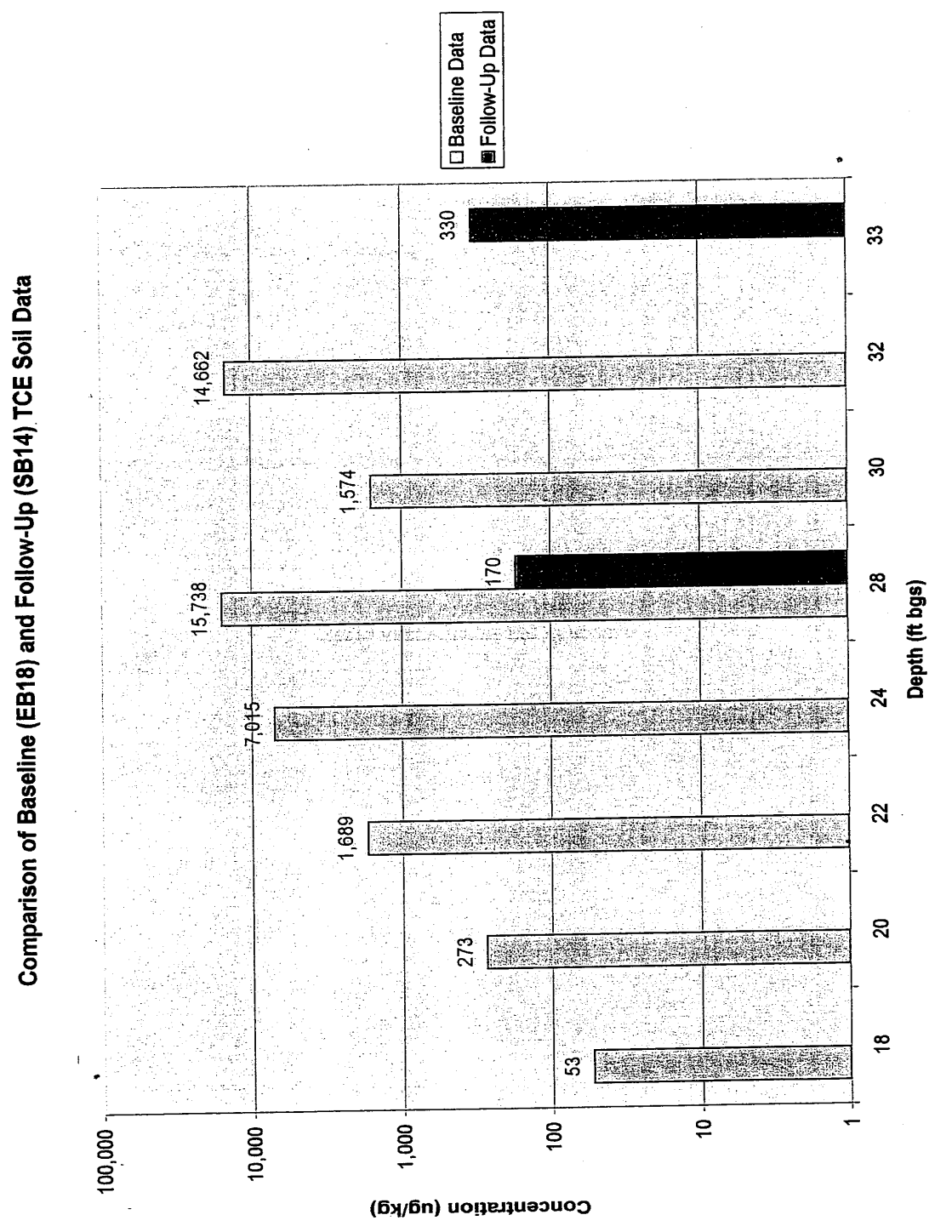




\section{APPENDIX B:}

COMPARISON OF PRE- AND POST-ISCO-LP TREATMENT MANGANESE SOIL CONCENTRATIONS

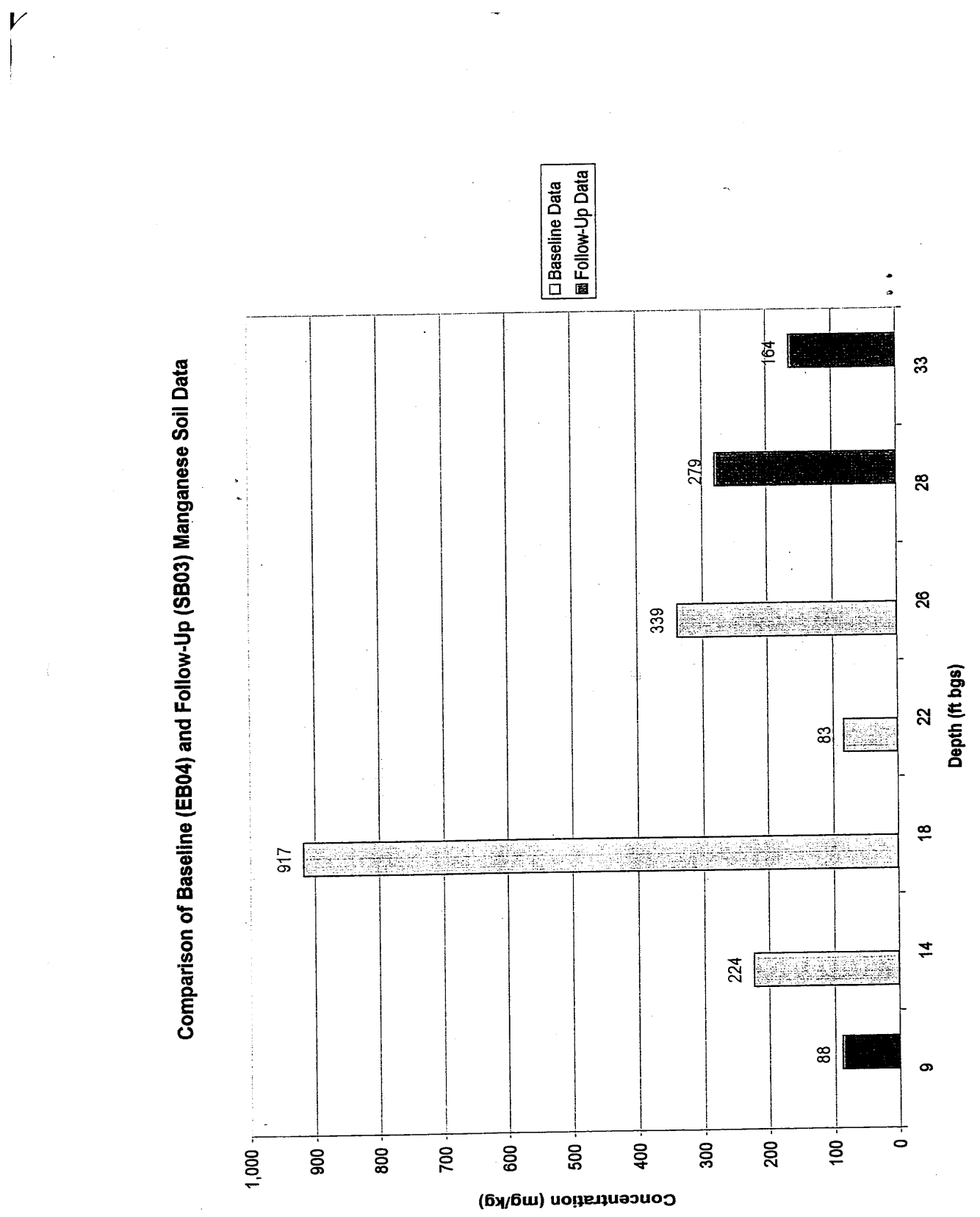




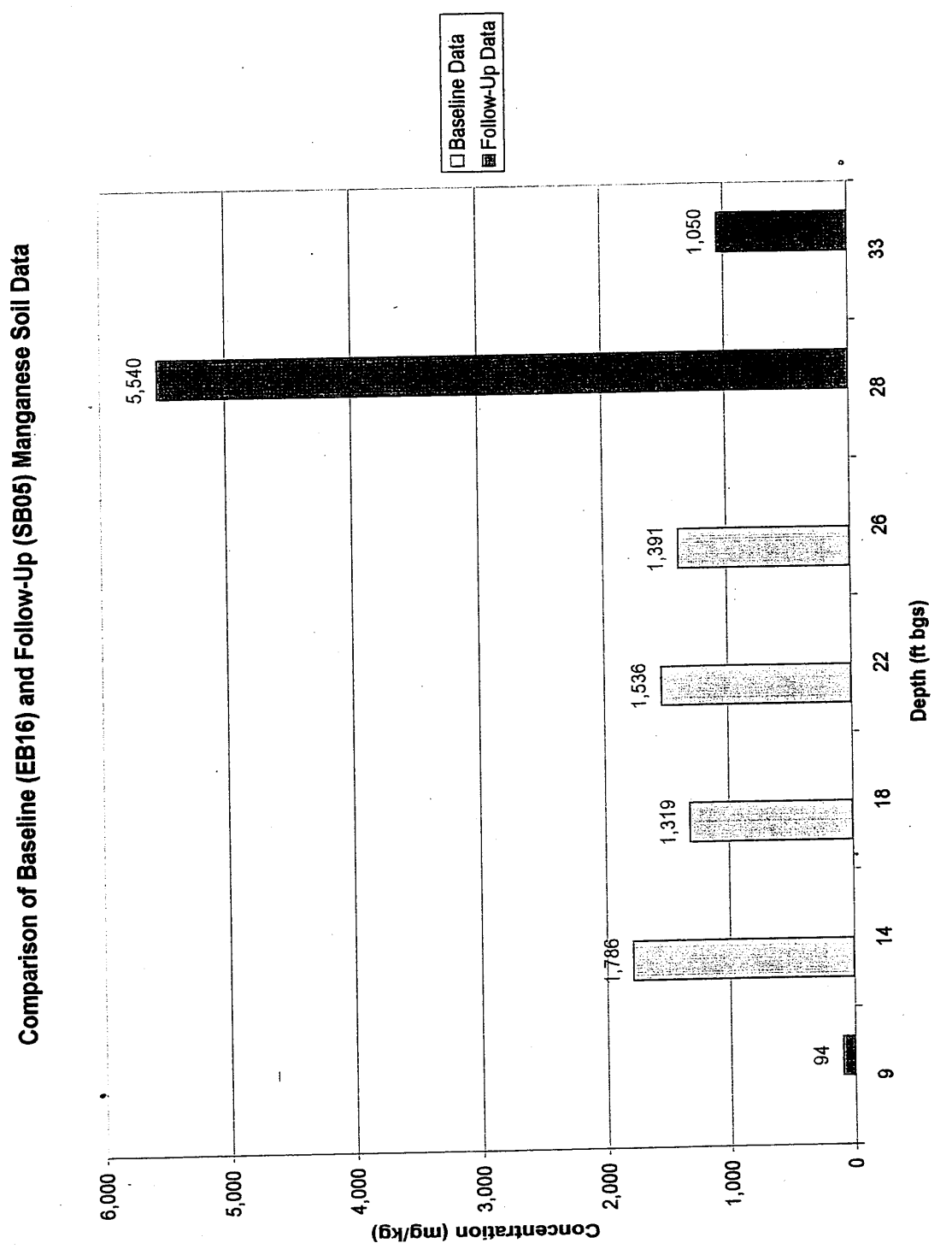


1

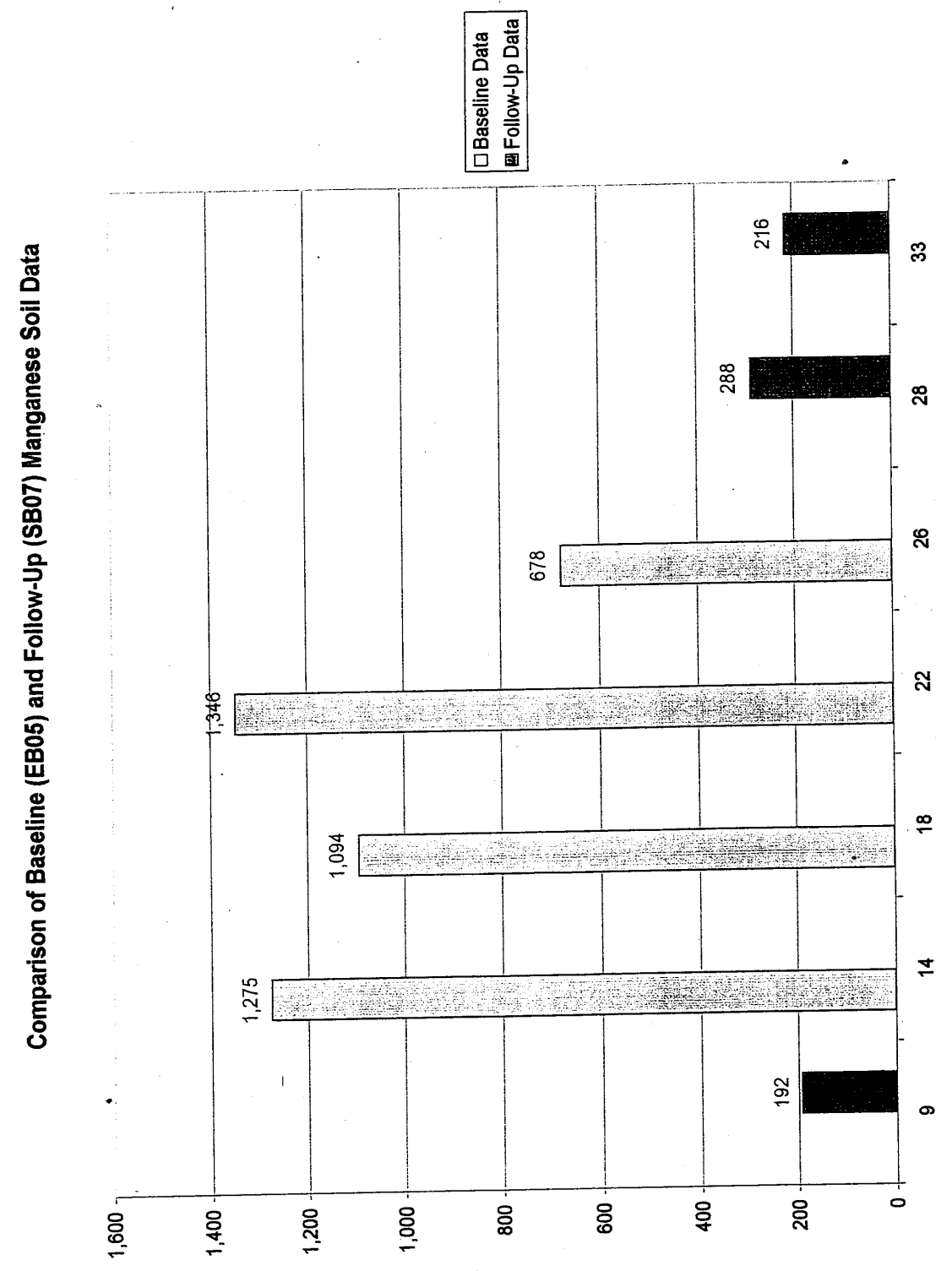


1

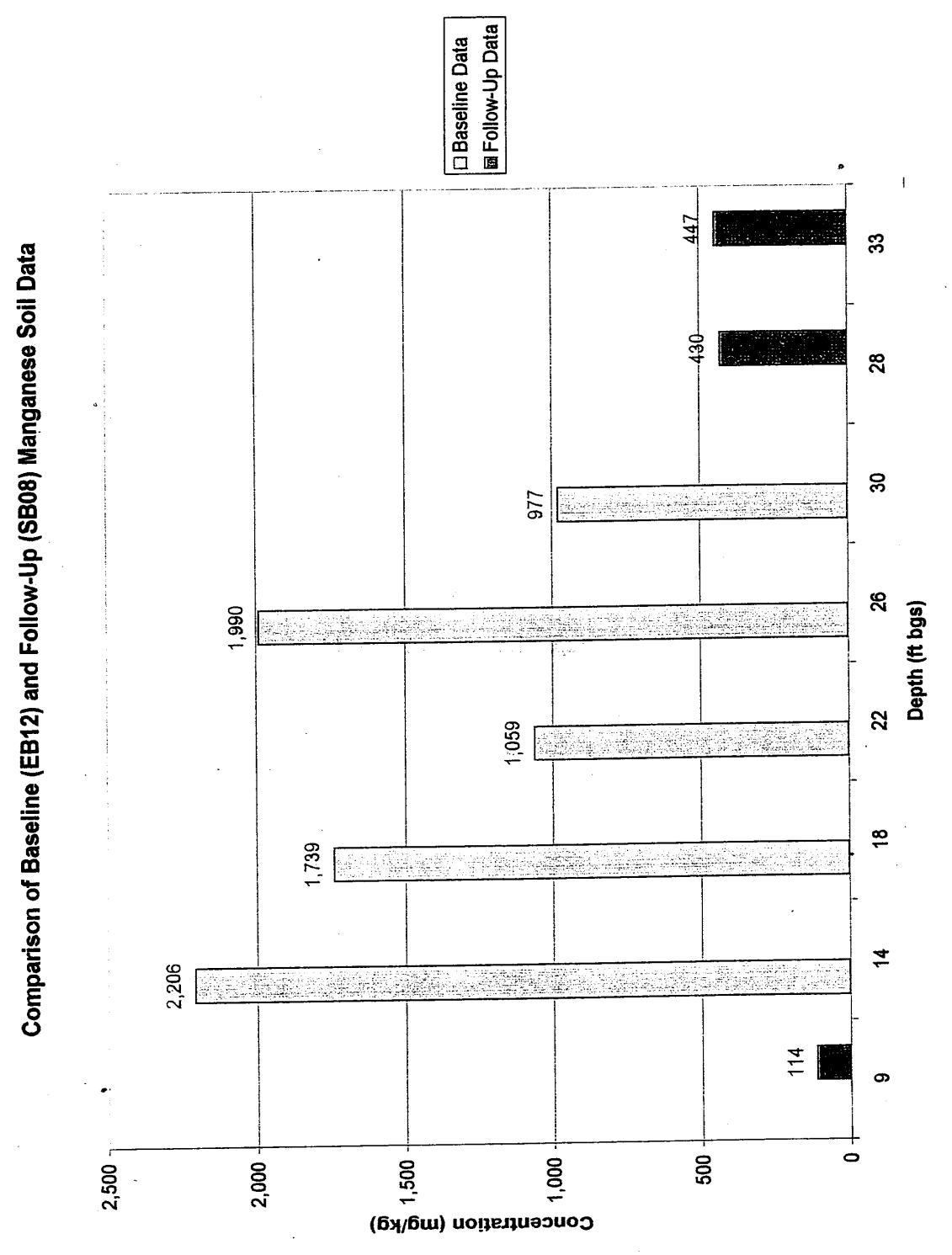




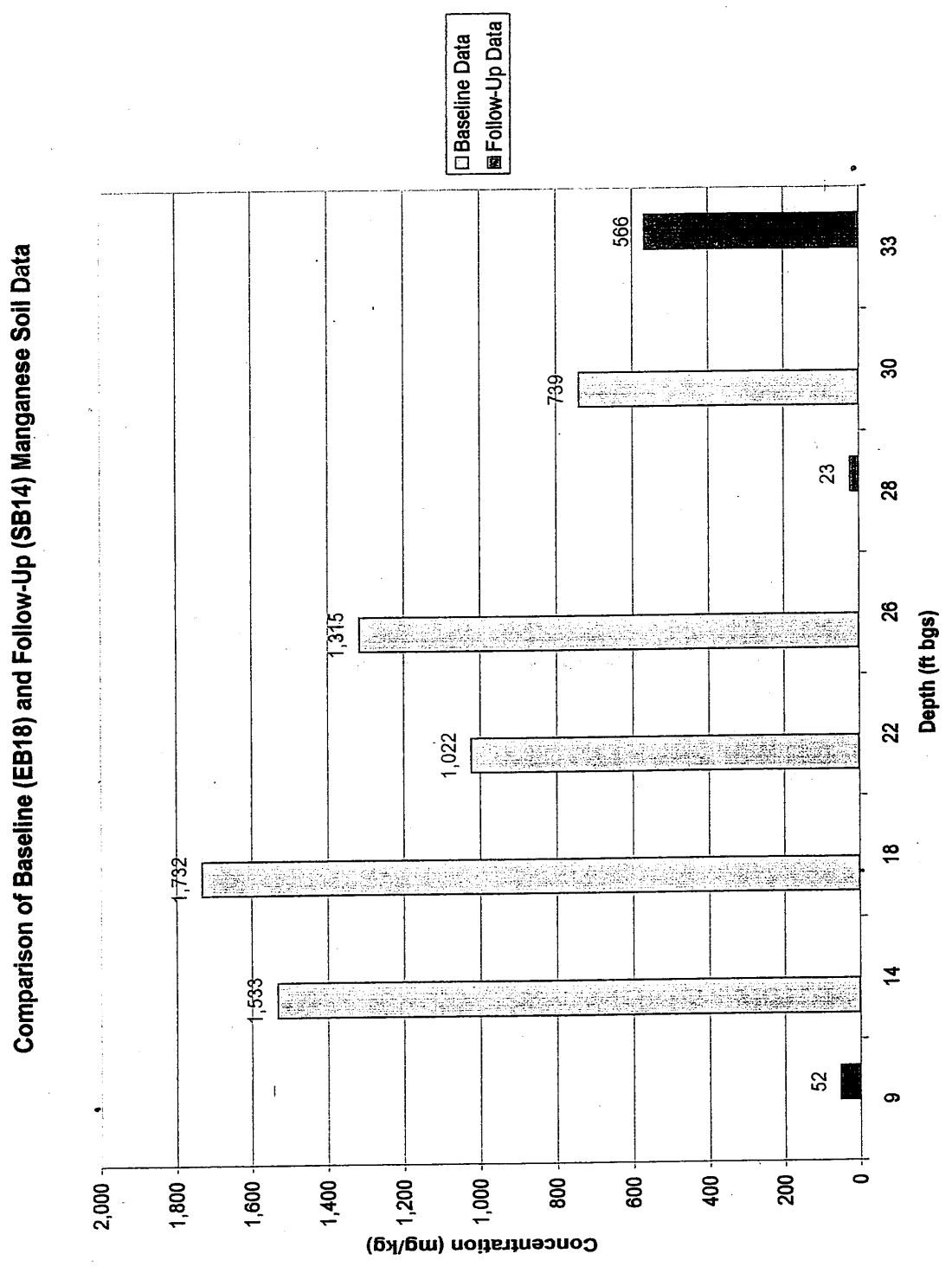




\section{INTERNAL DISTRIBUTION}

1. T. O. Early

2. S. D. Hildebrand

3. M. Z. Martin

4. O. R. West
5. Central Research Library

6-8. ESD Library

9-10. ORNL Laboratory Records-OSTI

11. ORNL Laboratory Records-RC

\section{EXTERNAL DISTRIBUTION}

12. Elizabeth Phillips, U.S. Department of Energy Oak Ridge Operations, P. O. Box 2001, Oak Ridge, TN 37831-8600 